Article

\title{
Dibutyltin(IV) and Tributyltin(IV) Derivatives of meso-Tetra(4-sulfonatophenyl)porphine Inhibit the Growth and the Migration of Human Melanoma Cells
}

\author{
Francesca Costantini ${ }^{1}$, Fabiana Di Leo ${ }^{1}$, Caterina Di Sano ${ }^{1}$, Tiziana Fiore ${ }^{2,3} \mathbb{1}$, \\ Claudia Pellerito ${ }^{2,3}$ and Giovanna Barbieri ${ }^{1, *(D)}$ \\ 1 Istituto per la Ricerca e l'Innovazione Biomedica (IRIB), Consiglio Nazionale delle Ricerche (CNR), \\ 90146 Palermo, Italy; francesca.costantini@irib.cnr.it (F.C.); fabyfdl@gmail.com (F.D.L.); \\ caterina.disano@irib.cnr.it (C.D.S.) \\ 2 Dipartimento di Fisica e Chimica, Università degli Studi di Palermo, 90128 Palermo, Italy; \\ tiziana.fiore@unipa.it (T.F.); claudia.pellerito@unipa.it (C.P.) \\ 3 Consorzio Interuniversitario di Ricerca in Chimica dei Metalli nei Sistemi Biologici (C.I.R.C.M.S.B.), \\ 1-70121 Bari, Italy \\ * Correspondence: giovanna.barbieri@irib.cnr.it
}

Received: 11 November 2019; Accepted: 29 November 2019; Published: 30 November 2019

\begin{abstract}
Melanoma is the most aggressive and deadly form of skin cancer, which is largely due to its propensity to metastasize. Therefore, with the aim to inhibit the growth and the metastatic dissemination of melanoma cells and to provide a novel treatment option, we studied the effects of the melanoma treatment with two organotin(IV) complexes of the meso-tetra(4-sulfonato-phenyl)porphine, namely $\left(\mathrm{Bu}_{2} \mathrm{Sn}\right)_{2}$ TPPS and $\left(\mathrm{Bu}_{3} \mathrm{Sn}\right)_{4}$ TPPS. In particular, we showed that nanomolar concentrations of $\left(\mathrm{Bu}_{2} \mathrm{Sn}\right)_{2}$ TPPS and $\left(\mathrm{Bu}_{3} \mathrm{Sn}\right)_{4}$ TPPS are sufficient to inhibit melanoma cell growth, to increase the expression of the full-length poly (ADP-ribose) polymerase (PARP-1), to induce the cell cycle arrest respectively at G2/M and G0/G1 through the inhibition of the Cyclin D1 expression and to inhibit cell colony formation. Nanomolar concentrations of $\left(\mathrm{Bu}_{2} \mathrm{Sn}\right)_{2}$ TPPS and $\left(\mathrm{Bu}_{3} \mathrm{Sn}\right)_{4}$ TPPS are also sufficient to inhibit the melanoma cell migration and the expression of some adhesion receptors. Moreover, we report that $\left(\mathrm{Bu}_{2} \mathrm{Sn}\right)_{2}$ TPPS and $\left(\mathrm{Bu}_{3} \mathrm{Sn}\right)_{4}$ TPPS act downstream of BRAF, mainly bypassing its functions, but targeting the STAT3 signalling protein. Finally, these results suggest that $\left(\mathrm{Bu}_{2} \mathrm{Sn}\right)_{2} \mathrm{TPPS}$ and $\left(\mathrm{Bu}_{3} \mathrm{Sn}\right)_{4}$ TPPS may be effective therapeutic strategies for their role in the inhibition of melanoma growth and migration.
\end{abstract}

Keywords: melanoma; organotin(IV); cellular growth; BRAF; cell cycle; migration

\section{Introduction}

Melanoma is the most aggressive form of skin cancer and unfortunately one of the most lethal cancers worldwide, whose incidence rates are increasing rapidly in western populations [1,2]. Indeed, the acquisition of invasive behaviour by metastatic melanoma cells is the key transition involved in the decrease of melanoma patient survival rates. In particular, the metastatic transformation of melanoma cells is a stepwise mechanism that depends on the increase of survival molecule mutations that inhibit apoptotic pathways, allowing survival to hypoxia and oxidative stress [3] and increasing the cellular migration and dissemination, which leads to the transformation of melanocytes into metastatic melanoma. Indeed, despite the fact targeted therapies and immunotherapies have changed significantly the metastatic melanoma treatment landscape [4], significant morbidity and mortality are still associated with metastatic disease, and in fact only $32 \%$ of patients with metastatic melanoma have a 5 -year median survival rate, compared to almost $93 \%$ of patients with early melanoma lesions [5]. 
Therefore, the melanoma field is in great need of studies to identify new efficient therapies suitable for overcoming the intrinsic survival features acquired by melanoma cells to promote proliferation and invasion. In this contest a group of organometallic compounds, the organotin complexes, widely accepted in oncology as potential anticancer drugs, is very interesting [6,7]. The general formula

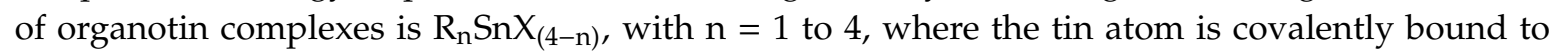
one or more organic alkyl or aryl groups $(R)$ as well as to inorganic or organic ligands $(X)[6]$. The nature and the number of the alkyl or aryl groups bound to the tin atoms of the organotin(IV) are crucial for the anticancer activity of the complexes, while the ligands play a key role addressing the organotin complexes to the target sites of the cells and modulating its cytotoxic activity [8-10]. Indeed, tin-based compounds can bind some membrane and cytoplasmic proteins such as receptors and glycoproteins, can cross lipid bilayer membranes and reach the nucleus, where they can directly interact with the DNA bases through intercalation, can also interact with the functional groups of the DNA grooves and with the phosphate of the DNA phosphodiester backbones as anchoring sites for the tin [11-13]. The consequences of these interactions are both the structural and functional alterations of the membranes and the induction of DNA damage that leads to the blockage of cell division and cell growth of organotin(IV)-treated cancer cells [6,8-10,14-16]. Moreover, the ligand molecules of the organotin(IV) complexes, modifying the reactivity, the lipophilicity, the configuration and the molecular structure of the complexes and therefore their binding activity and functions, play a significant role in modulating the anti-tumour activity of the organotin(IV) moieties [12,17]. In particular, porphyrins and porphyrin-based compounds are some interesting ligands for organotin(IV) moieties, due not only to the property of the porphyrin to accumulate and to be retained by a variety of malignant lesions [18], but also their function as drug delivery systems [19], bio-sensing and bio-imaging molecules [20]. Indeed, the organotin(IV) complexes have different mechanisms of action on different cancer cells and induce tumour cell death in a concentration dependent manner [21,22]. In particular, organotin(IV) complexes at higher concentrations, induce cancer cell death, but at lower concentrations organotin(IV) complexes show antitumoral activity, inhibiting the cancer cell growth and therefore opening a new field of study in the metal-pharmaceutical research area [21,22]. Therefore, with the aim to identify new potential chemotherapeutic drugs that can inhibit the growth and metastatic dissemination of human melanoma cells, we studied the effects of melanoma treatment with two organotin(IV) compounds, namely the dibutyltin(IV) and tributyltin(IV) derivatives of meso-tetra(4-sulfonatophenyl)porphine, $\left(\mathrm{Bu}_{2} \mathrm{Sn}\right)_{2} \mathrm{TPPS}$ and $\left(\mathrm{Bu}_{3} \mathrm{Sn}\right)_{4} \mathrm{TPPS}$. The complexes were synthesized as previously reported [8] and were isolated in the solid state as octahedral and trigonal-bipyramidal eq-R3Sn polymeric configurations, respectively, for $\left(\mathrm{Bu}_{2} \mathrm{Sn}\right)_{2}$ TPPS and $\left(\mathrm{Bu}_{3} \mathrm{Sn}\right)_{4}$ TPPS complexes, with the arylsulfonate groups behaving as monoanionic bidentate bridging ligands (Figure 1A,B).

We have previously reported the death due to apoptosis and in particular the activation of both the intrinsic and the extrinsic apoptotic pathways in human melanoma cells treated with micromolar concentrations of the $\left(\mathrm{Bu}_{2} \mathrm{Sn}\right)_{2} \mathrm{TPPS}$ and the $\left(\mathrm{Bu}_{3} \mathrm{Sn}\right)_{4} \mathrm{TPPS}$ [14,23-25]. In this paper we improved upon and expanded this field of research by identifying that nanomolar concentrations of $\left(\mathrm{Bu}_{2} \mathrm{Sn}\right)_{2} \mathrm{TPPS}$ and $\left(\mathrm{Bu}_{3} \mathrm{Sn}\right)_{4}$ TPPS that are sufficient to significantly induce the cell cycle arrest of some melanoma cell lines through the inhibition of cyclin D1 expression.

We also reported that in melanoma cells $\left(\mathrm{Bu}_{2} \mathrm{Sn}\right)_{2}$ TPPS and $\left(\mathrm{Bu}_{3} \mathrm{Sn}\right)_{4}$ TPPS mediate inhibition of cell colony formation as well as of the integrin and CAM adhesion receptors expression and therefore, the inhibition of melanoma cell motility. Moreover, we showed that $\left(\mathrm{Bu}_{2} \mathrm{Sn}\right)_{2} \mathrm{TPPS}$ and $\left(\mathrm{Bu}_{3} \mathrm{Sn}\right)_{4} \mathrm{TPPS}$ act downstream of BRAF, mainly bypassing its functions but probably targeting STAT3 signalling protein.

In conclusion, the compounds $\left(\mathrm{Bu}_{2} \mathrm{Sn}\right)_{2}$ TPPS and $\left(\mathrm{Bu}_{3} \mathrm{Sn}\right)_{4} \mathrm{TPPS}$, for their role in the regression of the growth and migration of melanoma that we show in this paper, could deeply interfere with the melanoma progression and metastatic dissemination as new strategies for an effective treatment of this highly invasive tumour type. 

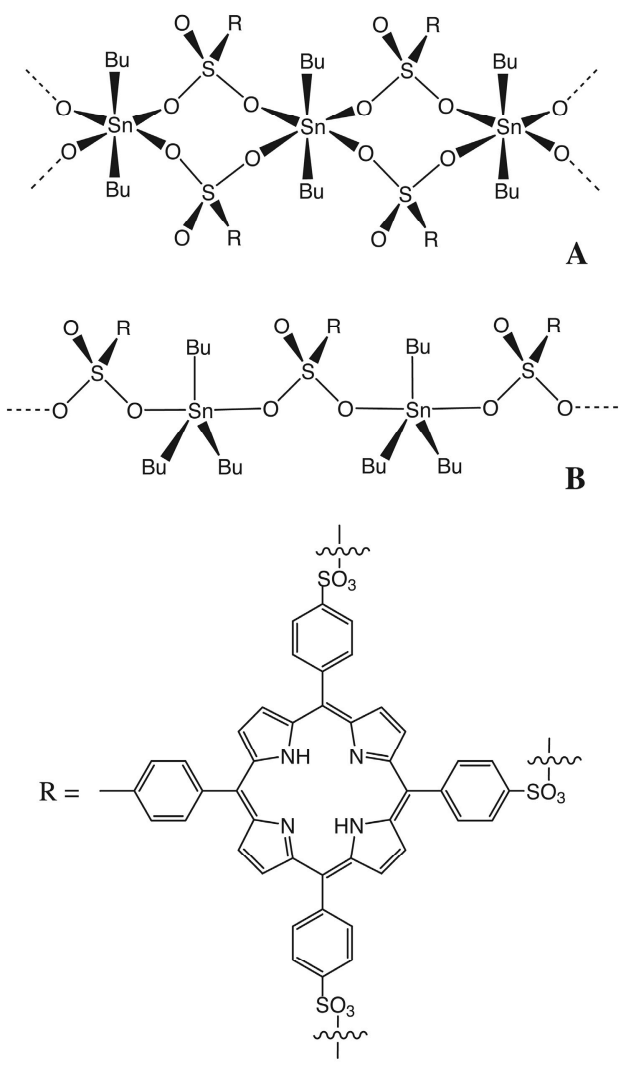

Figure 1. Polymeric octahedral configuration for $\left(\mathrm{Bu}_{2} \mathrm{Sn}\right)_{2} \mathrm{TPPS}(\mathrm{A})$ and polymeric trigonal-bipyramidal configuration for $\left(\mathrm{Bu}_{3} \mathrm{Sn}\right)_{4}$ TPPS $(\mathbf{B})$, as characterized in the solid state [8].

\section{Materials and Methods}

\subsection{Cell Lines, Antibodies, Chemicals and Reagents}

The A375 (ATCC-CRL-1619) [26], HT-144 (ATCC-HTB-63) and M74 melanoma cell lines (kindly provided by Prof. C. Alcaide-Loridan, Institut Jacques Monod, Paris Diderot University, Paris, France) harbouring the BRAF V600E mutation, were grown in RPMI 1640 supplemented with $10 \%$ FCS and $1 \%$ penicillin-streptomycin $\left(10,000 \mathrm{U} / \mathrm{mL}\right.$ and $10,000 \mu \mathrm{g} / \mathrm{mL}$, respectively) in $5 \% \mathrm{CO}_{2}$ at $37^{\circ} \mathrm{C}$. The A375 cell line was isolated from a primary tumour on the skin and can form metastatic foci in nude mice [27]; the HT-144 cell line was isolated from a metastatic site on subcutaneous tissue [28] and the M74 cell line was established from metastatic tumour fragments [29]. The organotin(IV) meso-tetra(4-sulfonatophenyl)porphinate complexes, $\left(\mathrm{Bu}_{2} \mathrm{Sn}\right)_{2} \mathrm{TPPS}$ (formula weight $\mathrm{FW}=1397$ ) and $\left(\mathrm{Bu}_{3} \mathrm{Sn}\right)_{4}$ TPPS (formula weight $\mathrm{FW}=2091$ ), were synthesized as previously reported [8] by refluxing, in dry methanol, $\mathrm{Bu}_{2} \mathrm{SnO}$ or $\left(\mathrm{Bu}_{3} \mathrm{Sn}\right)_{2} \mathrm{O}$ (gifts from Witco $\mathrm{GmbH}$, Bergkamen, Germany), and meso-tetra(4-sulfonatophenyl)porphine $\left(=\mathrm{H}_{4} \mathrm{TPPS}\right)$ of high purity, obtained from Porphyrin Products (Logan, UT, USA). The $\left(\mathrm{Bu}_{2} \mathrm{Sn}\right)_{2}$ TPPS and the $\left(\mathrm{Bu}_{3} \mathrm{Sn}\right)_{4}$ TPPS were dissolved in dimethylsulfoxide (DMSO) to obtain a $200 \mu \mathrm{M}$ stock solution before each treatment. Furthermore, the stock solutions were diluted in culture medium at various concentrations and before each treatment; in these solutions the final DMSO concentration did not exceed $0.05 \%(v / v)$. As a control, equal volumes of DMSO were added to untreated cells. The anti-pTyr-397 FAK motif, integrin $\beta 1$, ICAM- 1 and MCAM mouse monoclonal antibodies were obtained from BD Biosciences (Lexington, KY, USA). The anti-integrin $\beta 3$, FAK and cyclin D1 rabbit polyclonal antibodies and the anti-BRAF mouse monoclonal antibody were obtained from Santa Cruz (Santa Cruz, CA, USA). The anti-PARP-1 rabbit polyclonal antibody was purchased from Cell Signaling Technology (Leiden, The Netherlands). The mouse monoclonal antibody direct against $\beta$-actin was obtained from Sigma (St Louis, MO, USA). The anti-mouse and 
anti-rabbit Alexa Fluor 680 conjugated and the infrared dye-conjugated IRDye800 anti-mouse and anti-rabbit were purchased as secondary antibodies from Molecular Probes (Eugene, OR, USA) and LI-COR Biosciences (Lincoln, NE, USA), respectively. All other chemicals were of analytical grade and were obtained from Sigma Chemical Co. (St Louis, MO, USA), Merck/VWR Readington, NJ, USA) or J. T. Baker (Phillipsburg, NJ, USA).

\subsection{Cell Viability Assay (MTS Assay)}

A375 $\left(0.5 \times 10^{4}\right.$ per well $)$ or HT-144 and M74 human melanoma cells $\left(1 \times 10^{4}\right.$ per well $)$ were seeded in 96-well plates for $24 \mathrm{~h}$. Thereafter, the cells were treated with $\left(\mathrm{Bu}_{2} \mathrm{Sn}\right)_{2} \mathrm{TPPS}$ and $\left(\mathrm{Bu}_{3} \mathrm{Sn}\right)_{4} \mathrm{TPPS}$ or with DMSO as reported, for $24 \mathrm{~h}, 48 \mathrm{~h}$ and $72 \mathrm{~h}$ in triplicate and the cell viability was determined using the 3-(4,5-dimethylthiazol-2-yl)-5-(3-carboxymethoxyphenyl)-2-(4-sulfophenyl)-2H-tetrazolium (MTS) proliferation assay, following the instructions of the CellTiter-96 AQueous One Solution Cell Proliferation Assay (Promega, Madison, WI, USA). The plates were scanned at $490 \mathrm{~nm}$ in a 96-well plate reader after $30 \mathrm{~min}, 1 \mathrm{~h}, 1 \mathrm{~h} 30 \mathrm{~min}$ and $2 \mathrm{~h}$. Cell viability for each treatment was normalized against DMSO treated cells. The concentrations of $\left(\mathrm{Bu}_{2} \mathrm{Sn}\right)_{2} \mathrm{TPPS}$ and $\left(\mathrm{Bu}_{3} \mathrm{Sn}\right)_{4} \mathrm{TPPS}$ required to achieve $50 \%$ inhibition of the A375, HT-144 and M74 cell viability compared to untreated cell viability (IC 50 values), were calculated after $24 \mathrm{~h}, 48 \mathrm{~h}$ and $72 \mathrm{~h}$ of treatment using a dose-response curve (Excel, Microsoft, Redmond, WA, USA).

\subsection{Total Cell Extracts and Western Blot Analysis}

Semi-confluent A375, HT-144 and M74 human melanoma cells were treated with $\left(\mathrm{Bu}_{2} \mathrm{Sn}\right)_{2} \mathrm{TPPS}$ and $\left(\mathrm{Bu}_{3} \mathrm{Sn}\right)_{4}$ TPPS or with DMSO as reported, for $24 \mathrm{~h}, 48 \mathrm{~h}$ and $72 \mathrm{~h}$. Therefore, the cells were lysed as previously reported [30], in particular we used RIPA buffer (50 mM Tris-HCl pH 8, $150 \mathrm{mM}$ $\mathrm{NaCl}, 1 \% \mathrm{NP} 40,0.5 \% \mathrm{DOC}, 0.1 \% \mathrm{SDS}$ ) containing proteases and phosphatase inhibitors (4 mM PMSF and protease inhibitors cocktail, cocktail 2 and 3 of phosphatase inhibitors, Sigma, St Louis, MO, USA) for $30 \mathrm{~min}$ on ice. The cells in lysis buffer, were cleared of cellular debris by centrifugation at $12,000 \times \mathrm{g}$ at $4{ }^{\circ} \mathrm{C}$ for $30 \mathrm{~min}$. The Bradford protein assay (Bio-Rad laboratories $\mathrm{GmbH}$, München, Germany) was used to determine the protein concentration of the supernatants. Forty $\mu \mathrm{g}$ of total cell extracts were resolved on sodium dodecyl sulfate-polyacrylamide gel electrophoresis (SDS-PAGE) and absorbed to nitrocellulose membrane (Hybond ECL, GE Healthcare Biosciences, Pittsburgh, PA, USA). After overnight incubation at $4{ }^{\circ} \mathrm{C}$ in blocking buffer (LI-COR Biosciences, Lincoln, NE, USA), the nitrocellulose membrane was incubated at room temperature for $1 \mathrm{~h} 30 \mathrm{~min}$ with primary antibodies and anti-mouse or anti-rabbit infrared fluorescent-labelled secondary antibodies (IRDye800, LI-COR Biosciences, Lincoln, NE, USA and Alexa Fluor 680 conjugated, Molecular Probes, Eugene, OR, USA) diluted in blocking solution (LI-COR Biosciences, Lincoln, NE, USA) and TBS-Tween buffer. The protein bands were scanned and the band intensities of each western blot were quantified by densitometric analysis, using the Odyssey infrared imaging system (LI-COR Biosciences, Lincoln, NE, USA). In the histograms are reported the mean values of several western blot experiments of almost three different experiments and are expressed as a per cent of unstimulated cells, normalized for the actin amount.

\subsection{Cell Cycle Analysis}

Semiconfluent A374, HT-144 and M74 melanoma cells treated for $72 \mathrm{~h}$ with $\left(\mathrm{Bu}_{2} \mathrm{Sn}\right)_{2} \mathrm{TPPS}$ and $\left(\mathrm{Bu}_{3} \mathrm{Sn}\right)_{4}$ TPPS or with DMSO as reported, were washed twice with ice-cold PBS and resuspended at $1 \times 10^{6}$ cells $/ \mathrm{ml}$ in hypotonic fluorochrome solution ( $0.1 \%$ sodium citrate, $0.03 \%$ Nonidet P-40 and $50 \mu \mathrm{g} / \mathrm{ml}$ propidium iodide) for $30 \mathrm{~min}$ at room temperature in the dark. Therefore, the cells were acquired on a FACSCalibur ${ }^{\mathrm{TM}}$ flow cytometer, supported by CellQuest acquisition and data analysis software (Becton Dickinson, Mountain View, CA, USA). 


\subsection{Cell Colony Assay}

A374, HT-144 and M74 melanoma cells $\left(1.8 \times 10^{2}, 10.8 \times 10^{2}\right.$ and $18 \times 10^{2}$ cells, respectively) were seeded in a 12-well cell culture plate and treated for $72 \mathrm{~h}$ with $\left(\mathrm{Bu}_{2} \mathrm{Sn}\right)_{2} \mathrm{TPPS}$ and $\left(\mathrm{Bu}_{3} \mathrm{Sn}\right)_{4} \mathrm{TPPS}$ or with DMSO as reported. Afterwards, the treated and untreated cells were maintained in fresh medium for 7-14 days, were fixed in 100\% methanol and stained with $0.5 \%$ crystal violet in $20 \%$ methanol. Therefore, the plates were air dried, the colonies were photographed using a digital camera and counted.

\subsection{Cell Migration Assay}

The A375 and HT-144 melanoma cells were treated as reported with $\left(\mathrm{Bu}_{2} \mathrm{Sn}\right)_{2} \mathrm{TPPS}$ and $\left(\mathrm{Bu}_{3} \mathrm{Sn}\right)_{4} \mathrm{TPPS}$ or with DMSO for $72 \mathrm{~h}$. After treatment, as previously reported [30], $1.6 \times 10^{4}$ of A375 and HT-144 melanoma cells were plated in serum-free medium in the inner chamber of a 24-well culture plate (Falcon, Bredford, MA, USA) with a polyethylene terephthalate (PET) membrane (pore size, $8 \mu \mathrm{m}$; Falcon, Bredford, MA, USA) [31]. The lower wells were filled with RPMI supplemented with $10 \%$ FBS. After $16 \mathrm{~h}$ at $37^{\circ} \mathrm{C}$ the cells in the upper chamber were removed with a cotton swab and the migrated cells attached to the lower surface of the transwell membrane were fixed for $20 \mathrm{~min}$ with $100 \%$ methanol and stained for $1 \mathrm{~h}$ with $0.5 \%$ crystal violet in $20 \%$ methanol. After staining, all the cells on the lower side of the filters were counted under phase contrast microscope (Leica, Wetzlar, Germany).

\section{Results}

\subsection{Inhibition of Melanoma Cell Proliferation}

With the aim of identifying the minimum concentrations of $\left(\mathrm{Bu}_{2} \mathrm{Sn}\right)_{2} \mathrm{TPPS}$ and $\left(\mathrm{Bu}_{3} \mathrm{Sn}\right)_{4} \mathrm{TPPS}$ (Figure 1A,B) sufficient to inhibit the growth of the A375, HT-144 and M74 human melanoma cell lines, we analysed the cellular growth of melanoma cells treated with $\left(\mathrm{Bu}_{2} \mathrm{Sn}\right)_{2} \mathrm{TPPS}$ concentrations ranging from $100 \mathrm{nM}$ to $600 \mathrm{nM}$ and with $\left(\mathrm{Bu}_{3} \mathrm{Sn}\right)_{4} \mathrm{TPPS}$ ranging from $60 \mathrm{nM}$ to $120 \mathrm{nM}$, for $24 \mathrm{~h}, 48 \mathrm{~h}$ and $72 \mathrm{~h}$, through MTS assays (Figure 2). The results of these experiments showed that the treatment of A375 and HT-144 cells with $200 \mathrm{nM}$ and of M74 cells with $300 \mathrm{nM}$ of $\left(\mathrm{Bu}_{2} \mathrm{Sn}\right)_{2}$ TPPS and the treatment of A375, HT-144 and M74 cells with $80 \mathrm{nM}, 60 \mathrm{nM}$ and $100 \mathrm{nM}$ of $\left(\mathrm{Bu}_{3} \mathrm{Sn}\right)_{4}$ TPPS, respectively, induce the inhibition (Figure 2A, right panel, Figure 2B left panel and Figure 2C, left and right panels) or the decrease (Figure 2A, left panel and Figure 2B, right panel) of the cell proliferation to a greater extent after $48-72 \mathrm{~h}$ of treatment, compared to untreated cells (NT). Interestingly, the $\mathrm{IC}_{50}$ values obtained for both compounds are higher than the amounts required to inhibit or reduce the cell proliferation (Figure 2). The A375, the HT-144 and the M74 human melanoma cell lines express the mutated form V600E of BRAF, in the A375 and in the M74 cells the promoter of the telomerase reverse transcriptase (TERT) is mutated and in M74 cells the expression of p53 is very low, furthermore in the HT-144 cells also the Ataxia Telangiectasia Mutated (ATM) protein is mutated [32-34]. All these mutations could induce a different growth rate of melanoma cells and also different sensitivity to the treatment with $\left(\mathrm{Bu}_{2} \mathrm{Sn}\right)_{2} \mathrm{TPPS}$ and with $\left(\mathrm{Bu}_{3} \mathrm{Sn}\right)_{4}$ TPPS compounds. In particular, ATM is activated by DNA double-strand breaks (DSB), is involved in cell-cycle control, DSB repair and in the block of the cell cycle progression [35]. Therefore, the mutation of ATM in HT-144 cells could slow down the response to the $\left(\mathrm{Bu}_{3} \mathrm{Sn}\right)_{4}$ TPPS compound used in these experiments that probably, for its high DNA binding affinity, induces DNA damage in melanoma cells. Furthermore, in A375 and M74 melanoma cells, the mutation of TERT promoter, could be associated with increased TERT expression and cell survival [32]. 
A

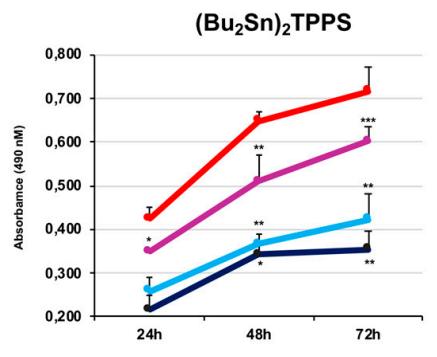

B
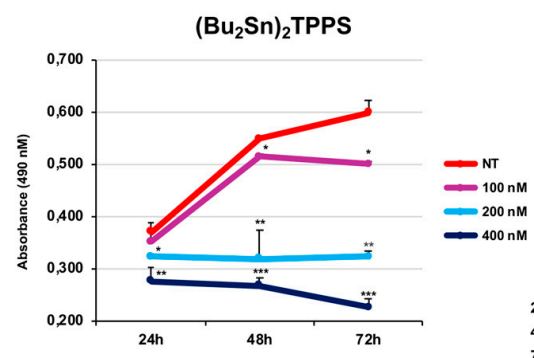

C

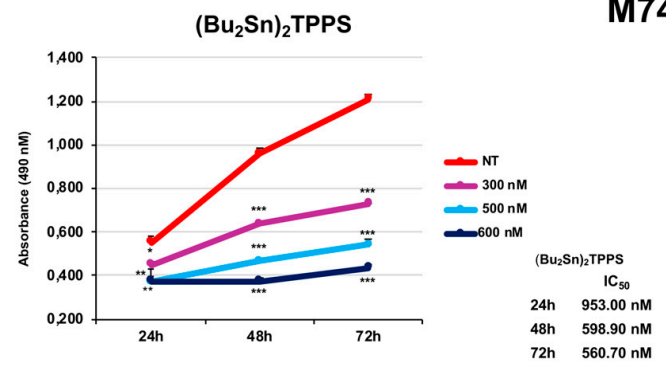

A375

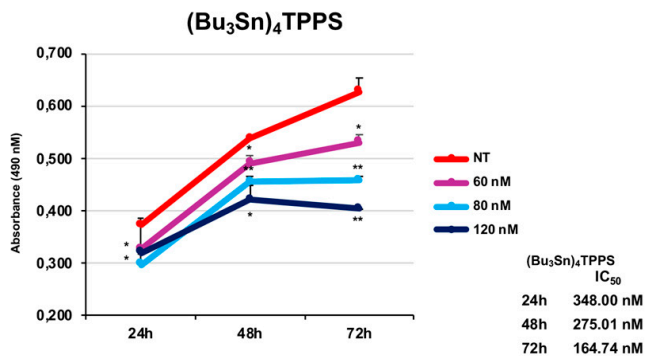

HT-144

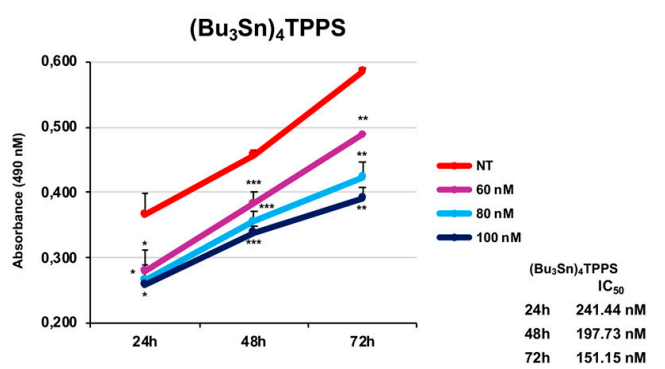

$\left(\mathrm{Bu}_{3} \mathrm{Sn}\right)_{4}$ TPPS

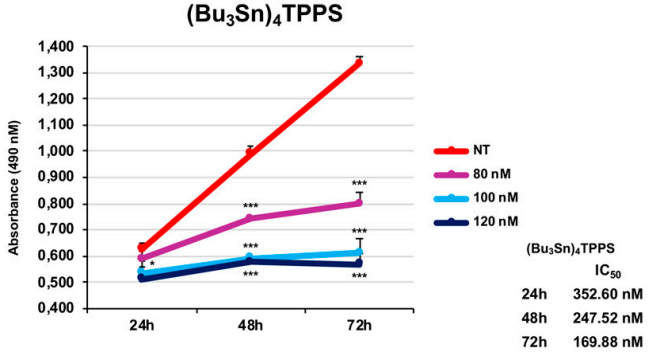

Figure 2. MTS assay of A375, HT-144 and M74 melanoma cells treated with $\left(\mathrm{Bu}_{2} \mathrm{Sn}\right)_{2} \mathrm{TPPS}$ and $\left(\mathrm{Bu}_{3} \mathrm{Sn}\right)_{4}$ TPPS. The (A) A375 cells were treated with $100 \mathrm{nM}, 200 \mathrm{nM}$ and $400 \mathrm{nM}$ of $\left(\mathrm{Bu}_{2} \mathrm{Sn}\right)_{2} \mathrm{TPPS}$ (left), or with $60 \mathrm{nM}, 80 \mathrm{nM}$ and $120 \mathrm{nM}$ of $\left(\mathrm{Bu}_{3} \mathrm{Sn}\right)_{4}$ TPPS (right); (B) the HT-144 cells were treated with 100 $\mathrm{nM}, 200 \mathrm{nM}$ and $400 \mathrm{nM}$ of $\left(\mathrm{Bu}_{2} \mathrm{Sn}\right)_{2} \mathrm{TPPS}$ (left), or with $60 \mathrm{nM}, 80 \mathrm{nM}$ and $100 \mathrm{nM}$ of $\left(\mathrm{Bu}_{3} \mathrm{Sn}\right)_{4} \mathrm{TPPS}$ (right); (C) the M74 cells were treated with $300 \mathrm{nM}, 500 \mathrm{nM}$ and $600 \mathrm{nM}$ of $\left(\mathrm{Bu}_{2} \mathrm{Sn}\right)_{2}$ TPPS (left), or with $80 \mathrm{nM}, 100 \mathrm{nM}$ and $120 \mathrm{nM}$ of $\left(\mathrm{Bu}_{3} \mathrm{Sn}\right)_{4} \mathrm{TPPS}$ (right) for $24 \mathrm{~h}, 48 \mathrm{~h}$ and $72 \mathrm{~h}$ and the cell proliferation rate of untreated (NT) and treated melanoma cells, was analysed through MTS assay. In the histograms (A-C) are reported the mean values of almost three different experiments performed in triplicate. The error bars indicate the standard deviation, statistical significance was analysed by the Student's $t$-test: ${ }^{*} p<0.05$ was considered significant; ${ }^{* *} p<0.01$ highly significant; ${ }^{* * *} p<0.001$ very highly significant. The $\mathrm{IC}_{50}$ values are also reported using the values of three different experiments performed in triplicate.

Furthermore, in the light of the results of the MTS assay, we treated the A375, HT-144 and M74 melanoma cells for $24 \mathrm{~h}, 48 \mathrm{~h}$ and $72 \mathrm{~h}$ with $250 \mathrm{nM}, 200 \mathrm{nM}$ and $300 \mathrm{nM}$, respectively, of $\left(\mathrm{Bu}_{2} \mathrm{Sn}\right)_{2}$ TPPS and with $80 \mathrm{nM}, 60 \mathrm{nM}$ and $100 \mathrm{nM}$ of $\left(\mathrm{Bu}_{3} \mathrm{Sn}\right)_{4} \mathrm{TPPS}$, to study the consequences of the melanoma treatment with low concentrations of the complexes. Indeed, in the following experiments we treated the A375 cells with $250 \mathrm{nM}$ of $\left(\mathrm{Bu}_{2} \mathrm{Sn}\right)_{2}$ TPPS instead of the $200 \mathrm{nM}$ used in MTS assay sufficient only to decrease the A375 proliferation rate. In particular, we analysed through western blot experiments, the expression of the poly (ADP-ribose) polymerase (PARP-1) (Figure 3), using an antibody direct against the full-length and the cleaved forms of PARP-1. Indeed, PARP-1 is a nuclear enzyme that plays a pivotal role in many processes such as the repair of DNA single and double strand breaks [36,37] and its cleavage is an apoptotic marker and an indicator of caspase activation [38]. Therefore, we showed that the treatment with $\left(\mathrm{Bu}_{2} \mathrm{Sn}\right)_{2} \mathrm{TPPS}$ (Figure $3 \mathrm{~A}-\mathrm{C}$, left and right panels) 
and with $\left(\mathrm{Bu}_{3} \mathrm{Sn}\right)_{4} \mathrm{TPPS}$ (Figure $3 \mathrm{~A}-\mathrm{C}$, middle and right panels), led to a significant increase of the full-length form of PARP-1 that is more evident in A375 and HT-144 melanoma cells treated with $\left(\mathrm{Bu}_{3} \mathrm{Sn}\right)_{4}$ TPPS (Figure $3 \mathrm{~A}, \mathrm{~B}$, middle and right panels), but do not induce the cleavage of PARP-1 in treated melanoma cells (Figure $3 \mathrm{~A}-\mathrm{C}$ ). Therefore, the increase of full-length form of PARP-1 but the lack of PARP-1 cleavage, strongly suggest that these treatments induce DNA damage but do not induce the death for apoptosis of treated melanoma cells.

A

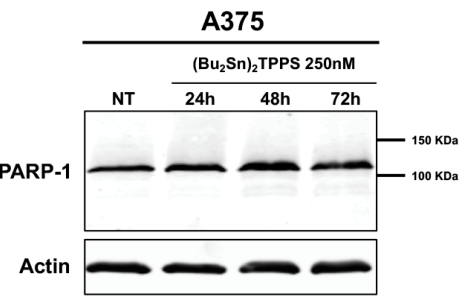

B

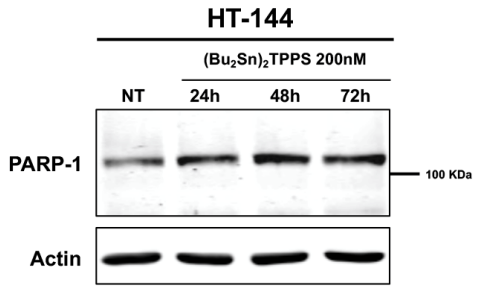

C

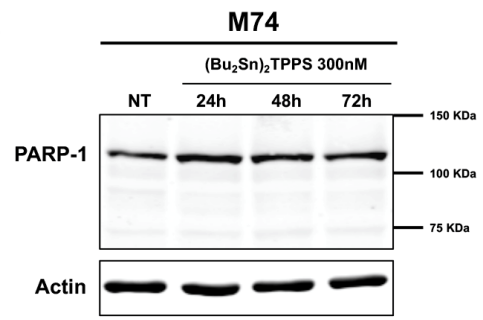

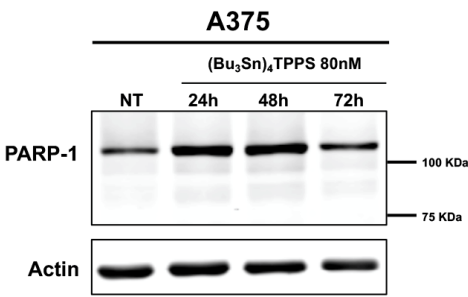
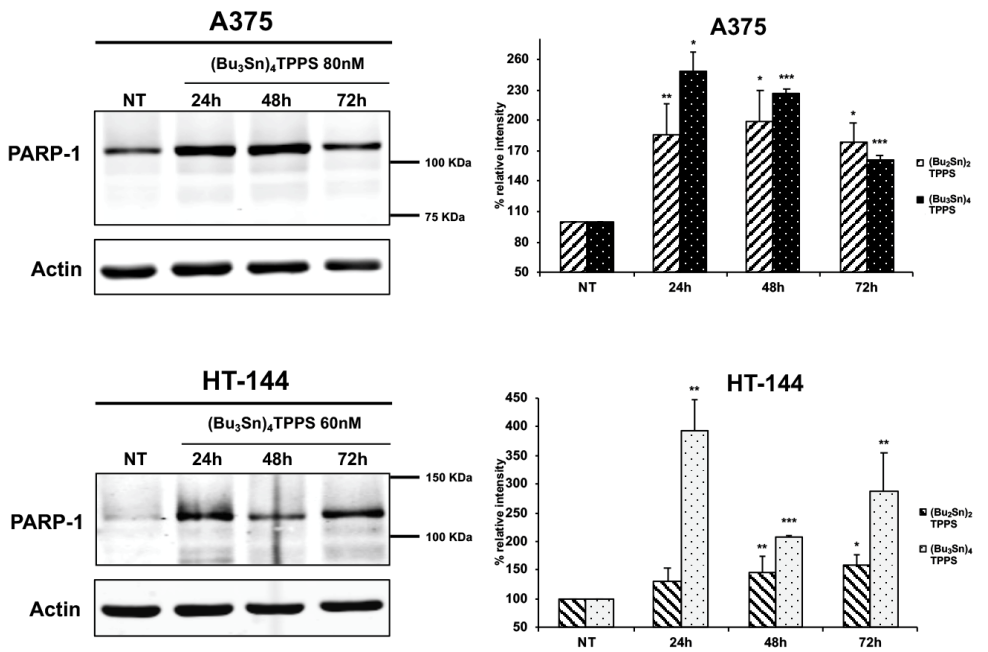

M74
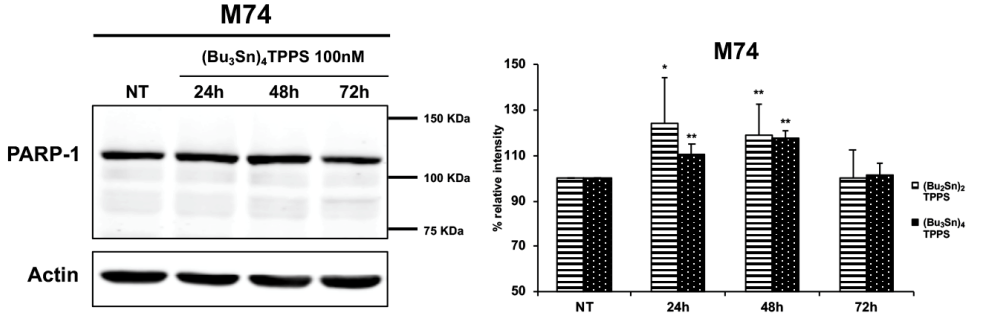

Figure 3. Kinetics of PARP-1 expression in A375, HT-144 and M74 melanoma cells treated with $\left(\mathrm{Bu}_{2} \mathrm{Sn}\right)_{2} \mathrm{TPPS}$ and $\left(\mathrm{Bu}_{3} \mathrm{Sn}\right)_{4}$ TPPS. The kinetics of PARP-1 expression was analysed through western blot experiments in (A) A375, (B) HT-144 and (C) M74 cell lines in response to the treatment with 250 $\mathrm{nM}, 200 \mathrm{nM}$ and $300 \mathrm{nM}$ of (Bu $\left.\mathrm{Bu}_{2} \mathrm{Sn}\right)_{2}$ TPPS (left and right panels) and with $80 \mathrm{nM}, 60 \mathrm{nM}$ and $100 \mathrm{nM}$ of $\left(\mathrm{Bu}_{3} \mathrm{Sn}\right)_{4} \mathrm{TPPS}$ respectively (middle and right panels) for $24 \mathrm{~h}, 48 \mathrm{~h}$ and $72 \mathrm{~h}$. The analysis of the $\beta$-actin expression (A, B and C, lower panels) was used to confirm the equal protein loading. The error bars indicate the standard deviation. The Student's t-test was used to the analysis of statistical significance: ${ }^{*} p<0.05$ was considered significant; ${ }^{* *} p<0.01$ highly significant; ${ }^{* * *} p<0.001$ very highly significant (A, B and C, right panels).

Furthermore, we analysed through western blot experiments, the expression of BRAF (Figure 4), a key signalling protein which plays a critical role in the regulation of cellular growth and proliferation [39]. In particular, we showed the increased expression of BRAF in treated cells compared to untreated cells (NT), that is more evident in melanoma cells treated with $\left(\mathrm{Bu}_{3} \mathrm{Sn}\right)_{4}$ TPPS (Figure $4 \mathrm{~A}-\mathrm{C}$, middle and right panels). Therefore, the inhibition of the cellular proliferation but the increase of the BRAF expression, strongly suggest that these treatments can bypass some of the BRAF functions. 
A

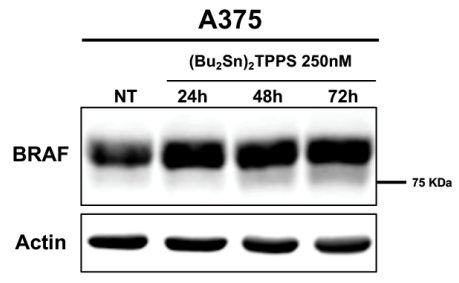

B

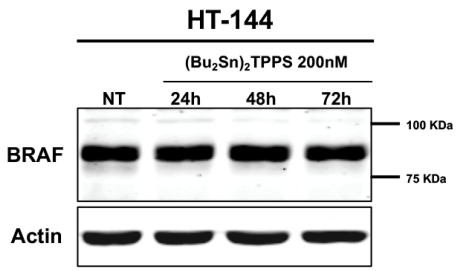

C

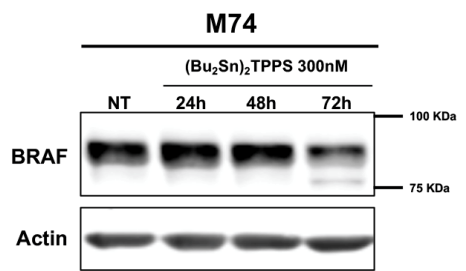

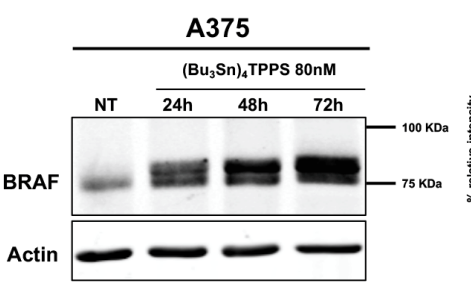
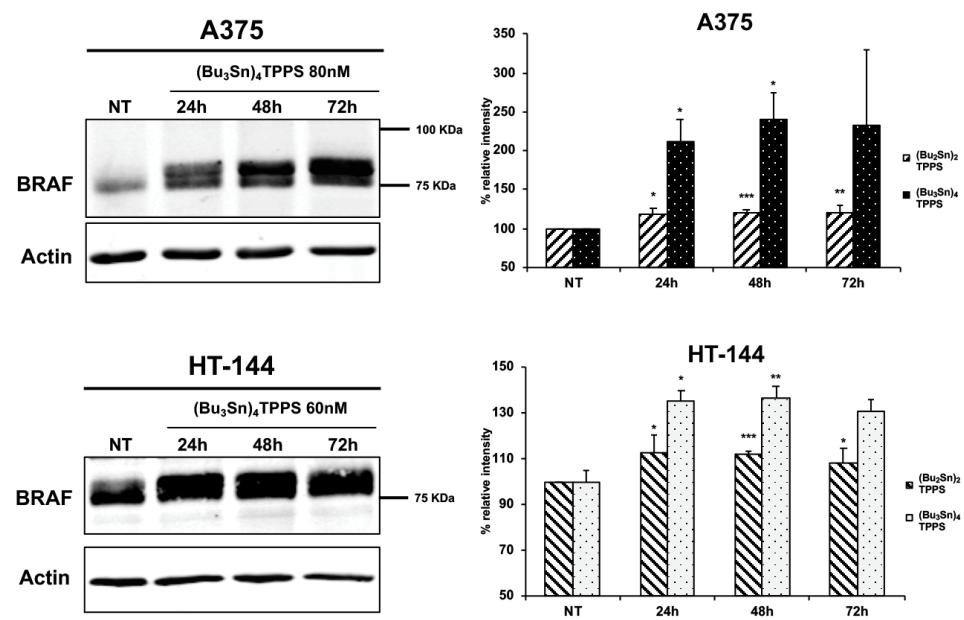

M74
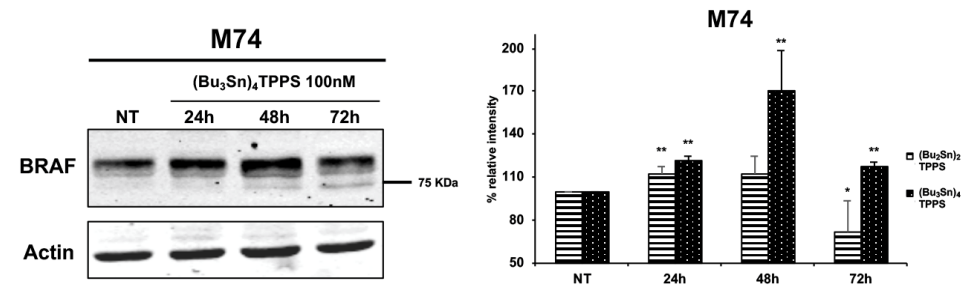

Figure 4. Kinetics of BRAF expression in A375, HT-144 and M74 melanoma cells treated with $\left(\mathrm{Bu}_{2} \mathrm{Sn}\right)_{2}$ TPPS and $\left(\mathrm{Bu}_{3} \mathrm{Sn}\right)_{4}$ TPPS. The kinetics of BRAF expression was analysed in (A) A375, (B) HT-144 and (C) M74 cell lines treated with $250 \mathrm{nM}, 200 \mathrm{nM}$ and $300 \mathrm{nM}$ of $\left(\mathrm{Bu}_{2} \mathrm{Sn}\right)_{2}$ TPPS (left and right panels) and with $80 \mathrm{nM}, 60 \mathrm{nM}$ and $100 \mathrm{nM}$ of $\left(\mathrm{Bu}_{3} \mathrm{Sn}\right)_{4}$ TPPS (middle and right panels) respectively, for $24 \mathrm{~h}, 48 \mathrm{~h}$ and $72 \mathrm{~h}$ through western blot experiments. The analysis of the $\beta$-actin expression (A, $\mathbf{B}$ and $\mathbf{C}$, lower panels) was used to confirm the equal protein loading. The error bars indicate the standard deviation. The Student's $t$-test was used to the analysis of statistical significance: ${ }^{*} p<0.05$ was considered significant; ${ }^{* *} p<0.01$ highly significant; ${ }^{* *} p<0.001$ very highly significant (A, B and C, right panels).

\subsection{Cell Cycle Arrest of Treated Melanoma Cells}

The highly conserved DNA-repair and cell cycle checkpoint pathways, are some mechanisms activated by the cells in response to DNA damage, to delay the cell cycle progression, to identify errors and to efficiently repair the damaged DNA [40]. Therefore, with the aim to further investigate the mechanisms used by these compounds to inhibit the cellular growth, we treated the A375, HT-144 and M74 cells with respectively $250 \mathrm{nM}, 200 \mathrm{nM}$ and $300 \mathrm{nM}$ of $\left(\mathrm{Bu}_{2} \mathrm{Sn}\right)_{2}$ TPPS and with $80 \mathrm{nM}, 60 \mathrm{nM}$ and $100 \mathrm{nM}$ of $\left(\mathrm{Bu}_{3} \mathrm{Sn}\right)_{4}$ TPPS for $72 \mathrm{~h}$ and the cell cycle distribution of treated and untreated melanoma cells was analysed by flow cytometry (Figure 5). In particular, we showed that the $\left(\mathrm{Bu}_{2} \mathrm{Sn}\right)_{2} \mathrm{TPPS}$ treatment decreases the rate of A375, HT-144 and M74 melanoma cells in G0/G1 phase (38.50\%, 37.43\% and $67.39 \%$ ) compared to untreated cells (NT) $(65.69 \%, 63.07 \%$ and $74.26 \%)$, but increases the rate of the cells in G2/M phase (34.98\%, 32.61\% and 29.72\%) compared to untreated cells (NT) $(20.46 \%$, $18.44 \%$ and $16.81 \%$ ) (Figure $5 \mathrm{~A}, \mathrm{C}, \mathrm{E})$. Otherwise, the $\left(\mathrm{Bu}_{3} \mathrm{Sn}\right)_{4} \mathrm{TPPS}$ treatment increases the rate of $\mathrm{A} 375$, HT-144 and M74 melanoma cells in G0/G1 phase (68.88\%, 65.96\% and $86.49 \%)$ compared to untreated cells (NT) $(63.68 \%, 61.44 \%$ and $73.41 \%)$, but decreases the rate of the cells in G2/M phase $(18.11 \%$, $16.52 \%$ and $7.01 \%)$ compared to untreated cells (NT) $(23.02 \%, 20.39 \%$ and $14.81 \%)$, (Figure 5B,D,F). Therefore, the results of these experiments show that $\left(\mathrm{Bu}_{2} \mathrm{Sn}\right)_{2}$ TPPS and the $\left(\mathrm{Bu}_{3} \mathrm{Sn}\right)_{4} \mathrm{TPPS}$ exert their anti-proliferative effects in melanoma cells through the blockage of cell cycle progression using different mechanisms (Figure 5). 
A375

A
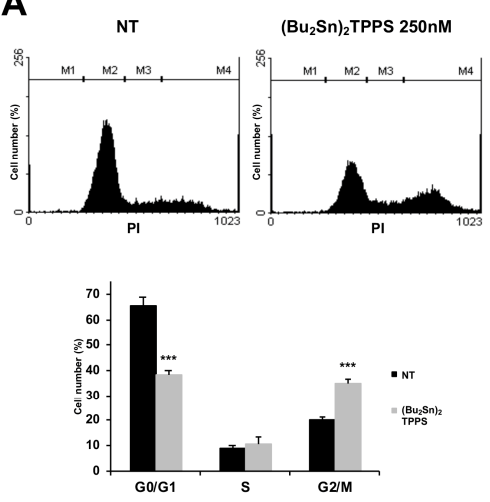

B
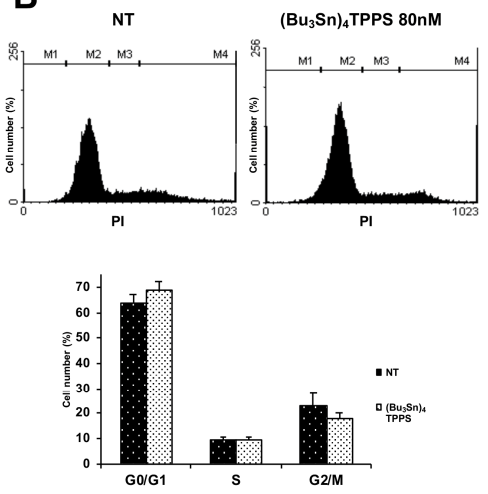

\section{HT-144}
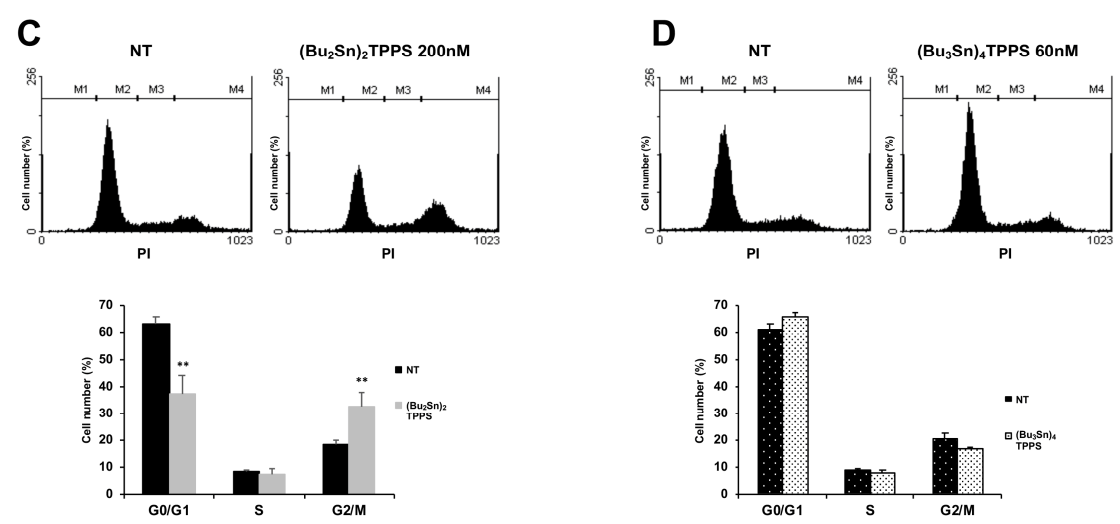

M74

E
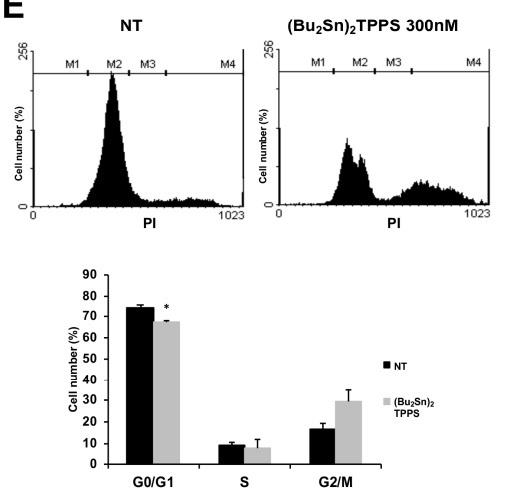
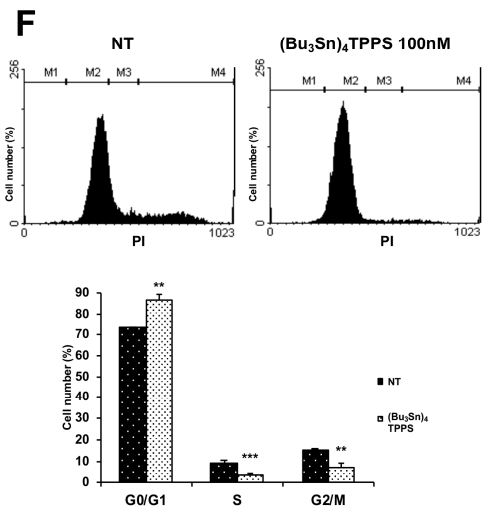

Figure 5. Cell-cycle analysis of A375, HT-144 and M74 melanoma cells treated with nanomolar concentration of $\left(\mathrm{Bu}_{2} \mathrm{Sn}\right)_{2}$ TPPS and $\left(\mathrm{Bu}_{3} \mathrm{Sn}\right)_{4}$ TPPS. Twenty thousand cells (events) per sample of untreated (NT) or treated for $72 \mathrm{~h}, \mathrm{~A} 375(\mathbf{A}, \mathbf{B})$, HT-144 (C,D) and M74 (E,F) melanoma cells with (A) $250 \mathrm{nM},\left(\text { C) } 200 \mathrm{nM} \text {, (E) } 300 \mathrm{nM} \text { of (Bu } \mathrm{Bu}_{2} \mathrm{Sn}\right)_{2}$ TPPS and with (B) $80 \mathrm{nM}$, (D) $60 \mathrm{nM}$, (F) $100 \mathrm{nM}$ of $\left(\mathrm{Bu}_{3} \mathrm{Sn}\right)_{4}$ TPPS respectively, were stained with PI. The fluorescence of PI-stained cells was analysed through flow cytometry to identify the percentage rate of cells in G0/G1, S and G2/M phases of the cell cycle. In the histograms (A-F, lower panels) the cell fractions of treated cells in G0/G1, S and G2/M phase of the cell cycle are expressed as a per cent of the cell fractions of untreated cells and as mean values of almost three different experiments, the error bars indicate the standard deviation and statistical significance was analysed by the Student's $t$-test: ${ }^{*} p<0.05$ was considered significant; ${ }^{* *} p<0.01$ highly significant; ${ }^{* * *} p<0.001$ very highly significant. 
Interestingly, each stage of the cell cycle is regulated by different complexes of the cyclin dependent kinases (CDKs) and of their regulatory partners, the cyclins [41]. Therefore, the expression of cyclin D1, a key regulator mainly of the G1/S [42] but also of the G2/M phases, was analysed by western blot experiments (Figure 6) on A375, HT-144 and M74 melanoma cells treated as reported for $24 \mathrm{~h}$, $48 \mathrm{~h}$ and $72 \mathrm{~h}$ with $\left(\mathrm{Bu}_{2} \mathrm{Sn}\right)_{2}$ TPPS and with $\left(\mathrm{Bu}_{3} \mathrm{Sn}\right)_{4}$ TPPS. We showed that, as expected, a larger decrease of the cyclin D1 expression in $\left(\mathrm{Bu}_{3} \mathrm{Sn}\right)_{4}$ TPPS-treated melanoma cells blocked in the G0/G1 phase (Figure $6 \mathrm{~A}-\mathrm{C}$, middle and right panels) compared to the cells treated with $\left(\mathrm{Bu}_{2} \mathrm{Sn}\right)_{2} \mathrm{TPPS}$ and blocked in $\mathrm{G} 2 / \mathrm{M}$ phase (Figure $6 \mathrm{~A}-\mathrm{C}$, left and right panels). Interestingly, these results suggest that the treatment with nanomolar concentration of $\left(\mathrm{Bu}_{2} \mathrm{Sn}\right)_{2} \mathrm{TPPS}$ and $\left(\mathrm{Bu}_{3} \mathrm{Sn}\right)_{4} \mathrm{TPPS}$ induce $\mathrm{G} 2 / \mathrm{M}$ and the G0/G1 cell cycle arrest, respectively, through the inhibition of cyclin D1 expression, although with different quantitative effects (Figure 6).

A

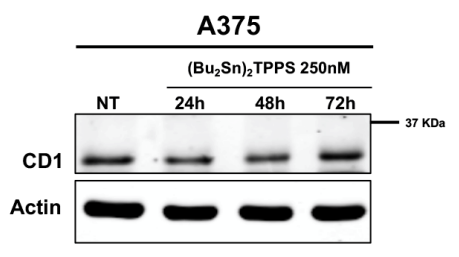

B

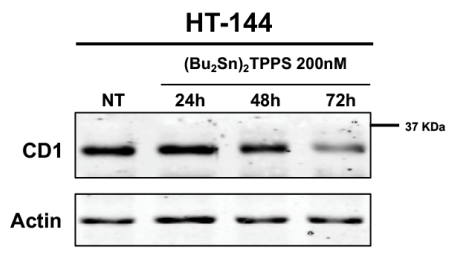

C

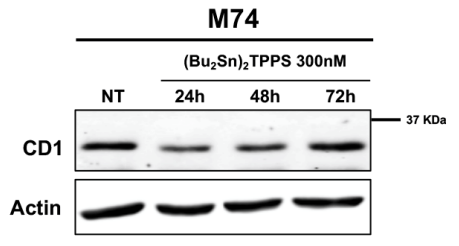

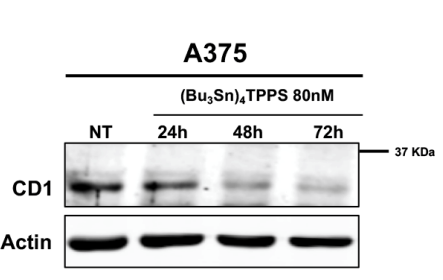

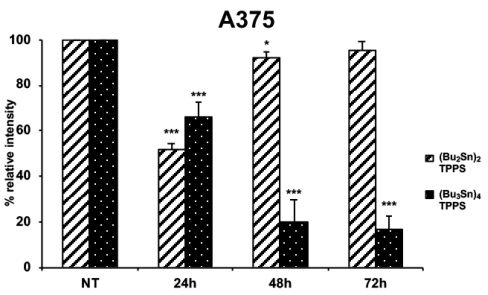

HT-144
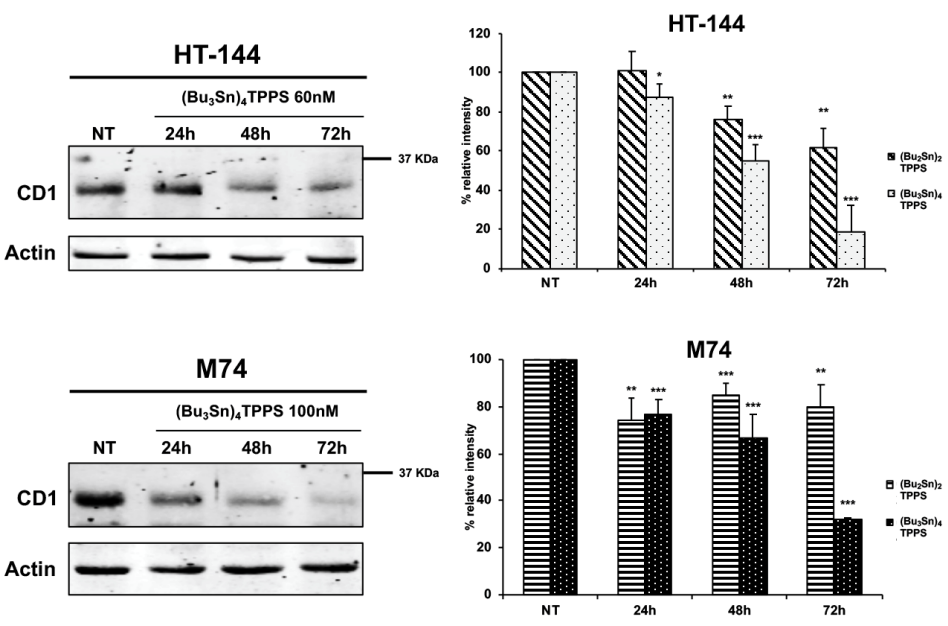

Figure 6. Kinetics of cyclin D1 expression in A375, HT-144 and M74 melanoma cells treated with $\left(\mathrm{Bu}_{2} \mathrm{Sn}\right)_{2}$ TPPS and $\left(\mathrm{Bu}_{3} \mathrm{Sn}\right)_{4}$ TPPS. The kinetics of cyclin D1 (CD1) expression was analysed in (A) A375, (B) HT-144 and (C) M74 cell lines treated with $250 \mathrm{nM}, 200 \mathrm{nM}$ and $300 \mathrm{nM}$ of $\left(\mathrm{Bu}_{2} \mathrm{Sn}\right)_{2}$ TPPS (left and right panels) and with $80 \mathrm{nM}, 60 \mathrm{nM}$ and $100 \mathrm{nM}$ of ( $\left(\mathrm{Bu}_{3} \mathrm{Sn}\right)_{4}$ TPPS (middle and right panels) respectively, for $24 \mathrm{~h}, 48 \mathrm{~h}$ and $72 \mathrm{~h}$, through western blot experiments. The analysis of the $\beta$-actin expression (A, B and C, lower panels) was used to confirm the equal protein loading. The error bars indicate the standard deviation. The Student's t-test was used to the analysis of statistical significance: ${ }^{*} p<0.05$ was considered significant; ${ }^{* *} p<0.01$ highly significant; ${ }^{* * *} p<0.001$ very highly significant $(\mathbf{A}$, B and C, right panels).

\subsection{Cell Colony Formation}

The hallmark of chemotherapeutic drugs is the inhibition of cellular proliferation as well as the reduction of cell viability. Therefore, the ability of the A375, HT-144 and M74 cell lines to form colonies after treatment for $72 \mathrm{~h}$ with $\left(\mathrm{Bu}_{2} \mathrm{Sn}\right)_{2} \mathrm{TPPS}(250 \mathrm{nM}, 200 \mathrm{nM}$ and $300 \mathrm{nM}$, respectively) and with $\left(\mathrm{Bu}_{3} \mathrm{Sn}\right)_{4} \mathrm{TPPS}(80 \mathrm{nM}, 60 \mathrm{nM}$ and $100 \mathrm{nM}$, respectively) was analysed (Figure 7). Interestingly, the $\left(\mathrm{Bu}_{2} \mathrm{Sn}\right)_{2}$ TPPS and the $\left(\mathrm{Bu}_{3} \mathrm{Sn}\right)_{4}$ TPPS treatments highly inhibited the ability of melanoma cells to form colonies, in particular the A375, HT-144 and M74 cell lines treated with $\left(\mathrm{Bu}_{2} \mathrm{Sn}\right)_{2} \mathrm{TPPS}$, displayed $11.44 \%$, $14.52 \%$ and $9.60 \%$, respectively, while the A375, HT-144 and M74 cell lines treated with $\left(\mathrm{Bu}_{3} \mathrm{Sn}\right)_{4} \mathrm{TPPS}$, 
displayed $2.63 \%, 6.71 \%$ and $1.62 \%$, respectively, of cell colony formation activity compared to untreated cells (Figure 7A-C). Therefore, our results showed that the treatment with nanomolar concentrations of $\left(\mathrm{Bu}_{2} \mathrm{Sn}\right)_{2} \mathrm{TPPS}$ and $\left(\mathrm{Bu}_{3} \mathrm{Sn}\right)_{4}$ TPPS reduces the cell viability and the survival rate of melanoma cells.

A

A375
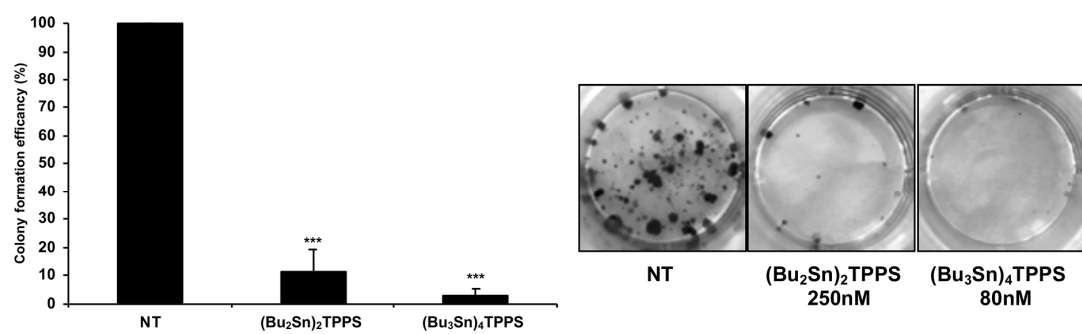

B

HT144
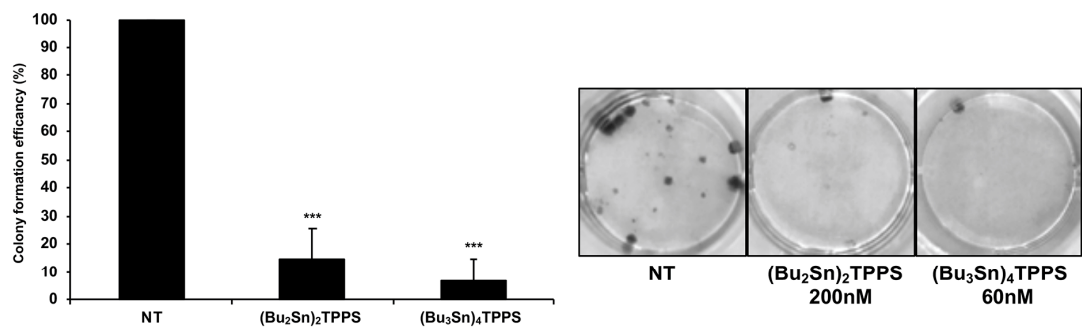

C

M74
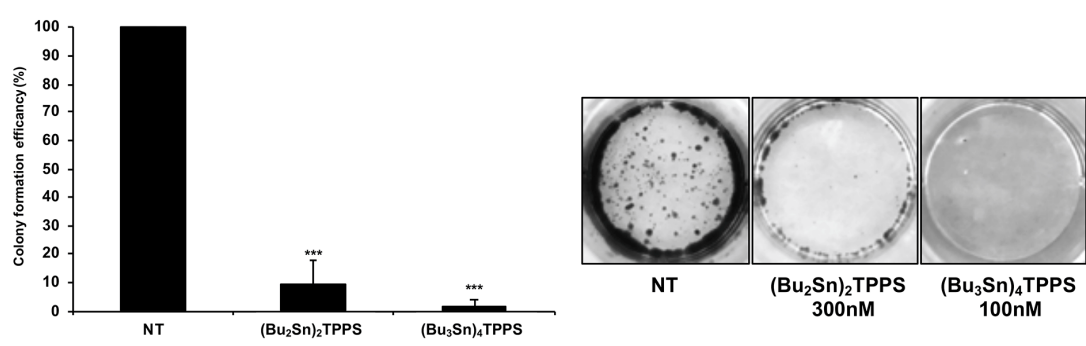

Figure 7. Cell colony assay of A375, HT-144 and M74 melanoma cells treated with nanomolar concentration of $\left(\mathrm{Bu}_{2} \mathrm{Sn}\right)_{2}$ TPPS and $\left(\mathrm{Bu}_{3} \mathrm{Sn}\right)_{4}$ TPPS. The A375 (A), the HT-144 (B) and the M74 (C) melanoma cells were treated for $72 \mathrm{~h}$ with 250,200 and $300 \mathrm{nM}$ of $\left(\mathrm{Bu}_{2} \mathrm{Sn}\right)_{2} \mathrm{TPPS}$ (left) and with 80, 60 and $100 \mathrm{nM}$ of $\left(\mathrm{Bu}_{3} \mathrm{Sn}\right)_{4}$ TPPS (right), respectively. After 7-14 days of growth in fresh medium, the colonies of treated and untreated cells were fixed, stained, photographed using a digital camera and counted. The colony formation efficiency of treated cells is the number of the colonies formed by treated cells expressed as a per cent of colonies formed by untreated cells (NT). These data are reported in the histograms (A-C, left panels) as the mean values of almost three different experiments performed in triplicate. The error bars indicate the standard deviation and statistical significance was analysed by the Student's $t$-test: ${ }^{* * *} p<0.001$ very highly significant.

\subsection{Expression of Adhesion Receptors and FAK Signalling Protein}

The adhesion receptors are important actors in melanoma metastatic dissemination defining the cellular shape and regulating cell mobility and invasiveness $[3,43]$. Therefore, to better understand the mechanisms used by $\left(\mathrm{Bu}_{2} \mathrm{Sn}\right)_{2}$ TPPS and $\left(\mathrm{Bu}_{3} \mathrm{Sn}\right)_{4}$ TPPS to inhibit the metastatic dissemination of melanoma cells, we analysed the expression of integrin $\beta 1$ and $\beta 3$ (Figures 8 and 9), MCAM and ICAM (Figure 10) adhesion receptors in A375 (Figure 8, Figure 10A,C) and HT-144 (Figure 9, Figure 10B,D) cell lines treated for $24 \mathrm{~h}, 48 \mathrm{~h}$ and $72 \mathrm{~h}$ with 250 and $200 \mathrm{nM}$ of $\left(\mathrm{Bu}_{2} \mathrm{Sn}\right)_{2} \mathrm{TPPS}$, respectively, and with 
80 and $60 \mathrm{nM}$ of $\left(\mathrm{Bu}_{3} \mathrm{Sn}\right)_{4}$ TPPS, respectively. In particular we showed in A375 and HT-144 melanoma cells treated with $\left(\mathrm{Bu}_{2} \mathrm{Sn}\right)_{2}$ TPPS, the decreased expression of integrin $\beta 1$ (Figures $8 \mathrm{~A}$ and $9 \mathrm{~A}$, left and right panels), integrin $\beta 3$ (Figures $8 \mathrm{~B}$ and $9 \mathrm{~B}$, left and right panels), MCAM (Figure 10A, B, left and right panels) and ICAM (Figure 10C,D, left and right panels) adhesion receptors, with the exception of the steady state level expression of integrin $\beta 3$ after $72 \mathrm{~h}$ of treatment in both cell lines (Figures $8 \mathrm{~B}$ and $9 \mathrm{~B}$, left and right panels), compared to untreated cells (NT).

A

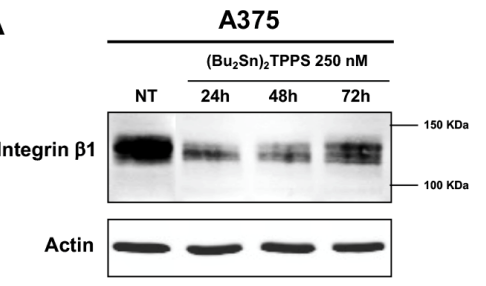

B

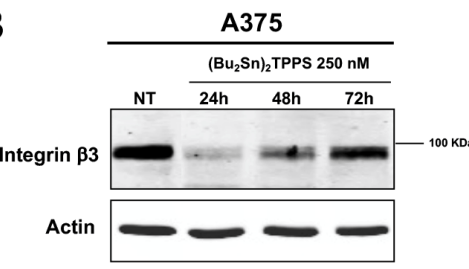

C

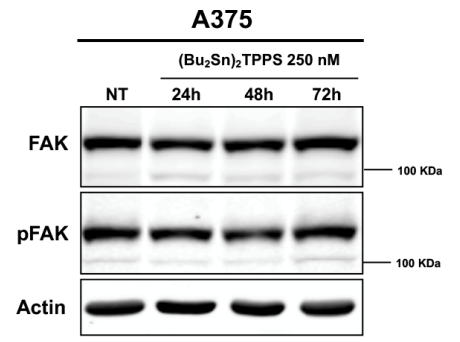

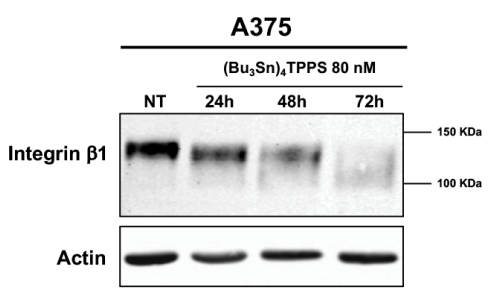
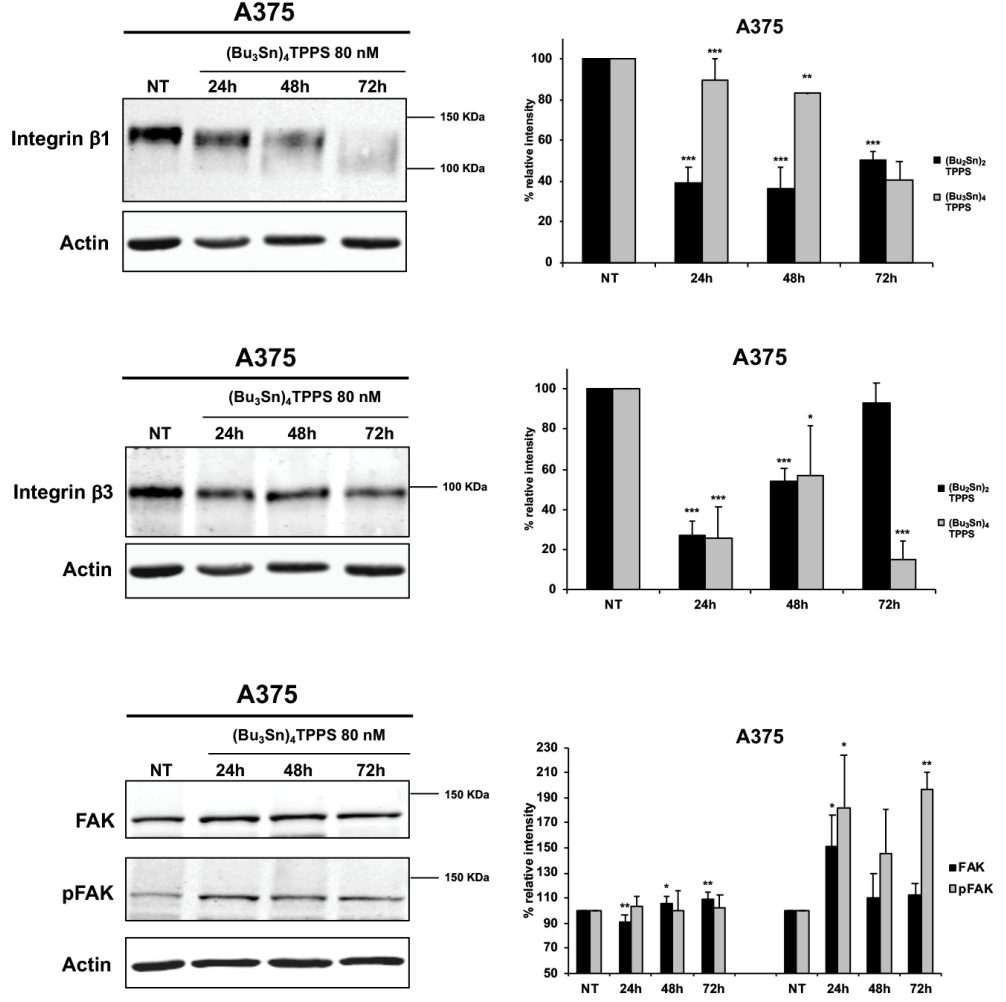

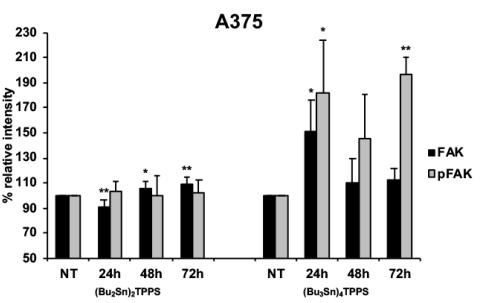

Figure 8. Kinetics of the integrins and FAK expression in A375 cells treated with $\left(\mathrm{Bu}_{2} \mathrm{Sn}\right)_{2} \mathrm{TPPS}$ and $\left(\mathrm{Bu}_{3} \mathrm{Sn}\right)_{4}$ TPPS. The kinetics of $(\mathbf{A})$ integrin $\beta 1$, (B) integrin $\beta 3$ adhesion receptors and of $(\mathbf{C})$ FAK and pFAK expression was analysed in A375 melanoma cells treated with $250 \mathrm{nM}$ of $\left(\mathrm{Bu}_{2} \mathrm{Sn}\right)_{2} \mathrm{TPPS}(\mathrm{A}, \mathrm{B}$ and $\mathrm{C}$, left and right panels) and with $80 \mathrm{nM}$ of $\left(\mathrm{Bu}_{3} \mathrm{Sn}\right)_{4} \mathrm{TPPS}$ (A, B and C, middle and right panels) for $24 \mathrm{~h}, 48 \mathrm{~h}$ and $72 \mathrm{~h}$, through western blot experiments. The analysis of the $\beta$-actin expression (A, B and C, lower panels) was used to confirm the equal protein loading. The error bars indicate the standard deviation. The Student's $t$-test was used to the analysis of statistical significance: ${ }^{*} p<0.05$ was considered significant; ** $p<0.01$ highly significant; ${ }^{* * *} p<0.001$ very highly significant $(\mathbf{A}, \mathbf{B}$ and C, right panels).

The $\left(\mathrm{Bu}_{3} \mathrm{Sn}\right)_{4}$ TPPS treatment induces the decreased expression of integrin $\beta 1$ in both cell lines (Figures $8 \mathrm{~A}$ and $9 \mathrm{~A}$, middle and right panels), while the expression of integrin $\beta 3$ decreased in $\mathrm{A} 375$ cells (Figure 8B, middle and right panels) but increased in HT-144 cells (Figure 9B, middle and right panels), compared to untreated cells (NT).

Finally, the $\left(\mathrm{Bu}_{3} \mathrm{Sn}\right)_{4}$ TPPS treatment induces in both cell lines the increased expression of MCAM (Figure 10A,B, middle and right panels) as well as the decreased expression of ICAM (Figure 10C,D, middle and right panels) with the exception of the steady state level expression of ICAM after $72 \mathrm{~h}$ of treatment in HT-144 cells (Figure 10D, middle and right panels). 
A

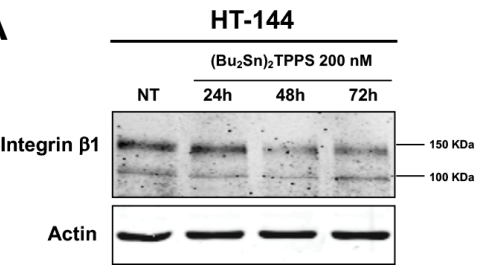

B
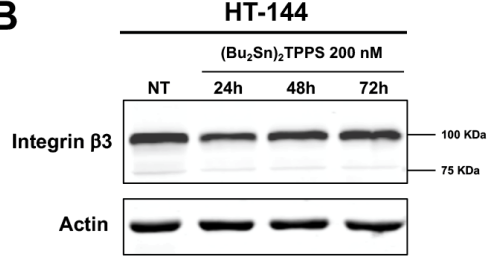

C

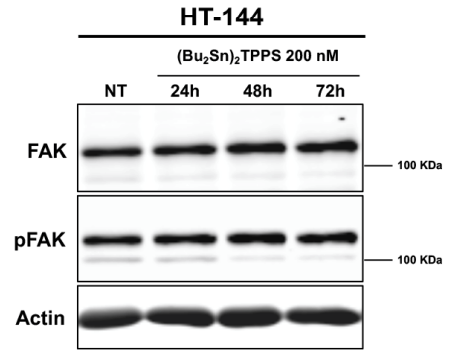

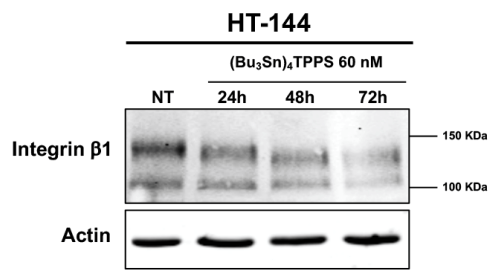
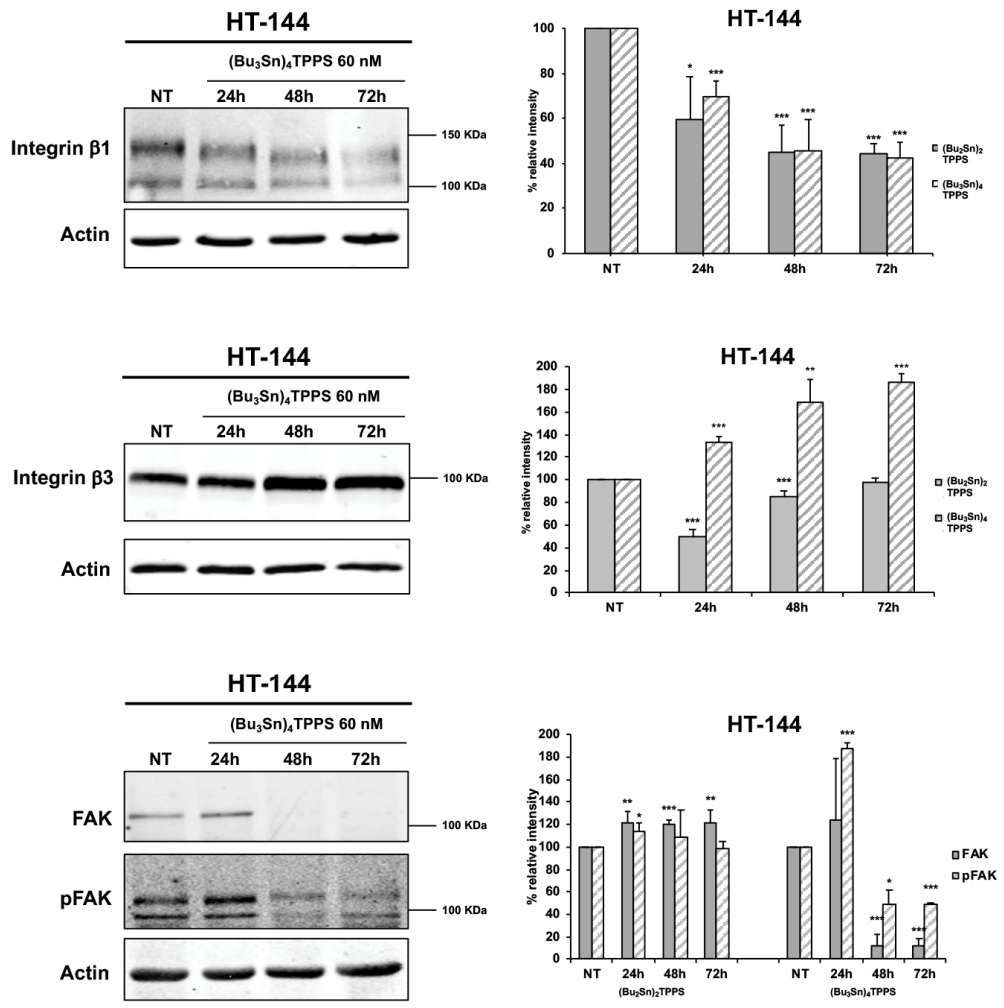

Figure 9. Kinetics of the integrins and FAK expression in HT-144 cells treated with $\left(\mathrm{Bu}_{2} \mathrm{Sn}\right)_{2} \mathrm{TPPS}$ and $\left(\mathrm{Bu}_{3} \mathrm{Sn}\right)_{4}$ TPPS. The kinetics of $(\mathbf{A})$ integrin $\beta 1,(\mathbf{B})$ integrin $\beta 3$ adhesion receptors and of $(\mathbf{C})$ FAK and pFAK expression was analysed in HT-144 melanoma cells treated with $200 \mathrm{nM}$ of $\left(\mathrm{Bu}_{2} \mathrm{Sn}\right)_{2} \mathrm{TPPS}(\mathrm{A}, \mathbf{B}$ and $\mathbf{C}$, left and right panels) and with $60 \mathrm{nM}$ of $\left(\mathrm{Bu}_{3} \mathrm{Sn}\right)_{4}$ TPPS (A, B and C, middle and right panels) for $24 \mathrm{~h}, 48 \mathrm{~h}$ and $72 \mathrm{~h}$, through western blot experiments. The analysis of the $\beta$-actin expression (A, B and C, lower panels) was used to confirm the equal protein loading. The error bars indicate the standard deviation. The Student's $t$-test was used to the analysis of statistical significance: ${ }^{*} p<0.05$ was considered significant; ${ }^{* *} p<0.01$ highly significant; ${ }^{* * *} p<0.001$ very highly significant $(\mathbf{A}, \mathbf{B}$ and $\mathrm{C}$, right panels).

Integrin signalling leads to the activation of FAK through the auto-phosphorylation of the Tyr-397 [44], therefore, we analysed in treated and untreated (NT) melanoma cells, the expression and the activation of FAK signalling protein (Figures $8 \mathrm{C}$ and $9 \mathrm{C}$ ) and we showed in $\left(\mathrm{Bu} \mathrm{u}_{2} \mathrm{Sn}\right)_{2}$ TPPS-treated cells that the expression and the activation of FAK are almost at the steady state level in both cell lines (Figures $8 \mathrm{C}$ and $9 \mathrm{C}$, left and right panels). Furthermore, we showed that the FAK expression and activation increase in $\left(\mathrm{Bu}_{3} \mathrm{Sn}\right)_{4}$ TPPS treated $\mathrm{A} 375$ cells, (Figure $8 \mathrm{C}$, middle and right panels), but decrease in HT-144 cells treated with $\left(\mathrm{Bu}_{3} \mathrm{Sn}\right)_{4} \mathrm{TPPS}$ for $48 \mathrm{~h}$ and $72 \mathrm{~h}$, (Figure 9C, middle and right panels). In conclusion, these results collectively showed that the treatment with nanomolar concentrations of $\left(\mathrm{Bu}_{2} \mathrm{Sn}\right)_{2}$ TPPS and $\left(\mathrm{Bu}_{3} \mathrm{Sn}\right)_{4}$ TPPS induces in melanoma cells, although with different quantitative effects, the decreased expression of integrin and CAM adhesion receptors and in HT-144 cells treated with $\left(\mathrm{Bu}_{3} \mathrm{Sn}\right)_{4}$ TPPS, the decreased expression and activation of FAK, thus suggesting that these complexes could inhibit the migration and metastatic dissemination of melanoma cells using different mechanisms. 
A

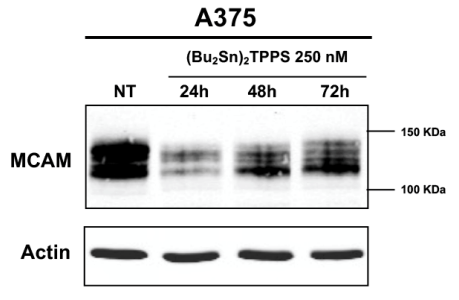

B

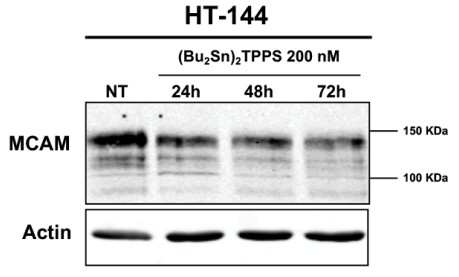

C

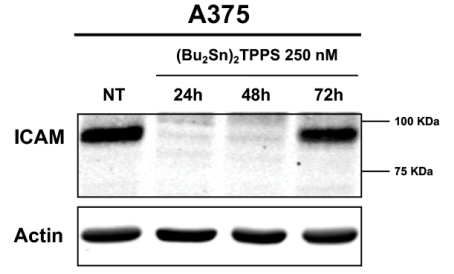

D

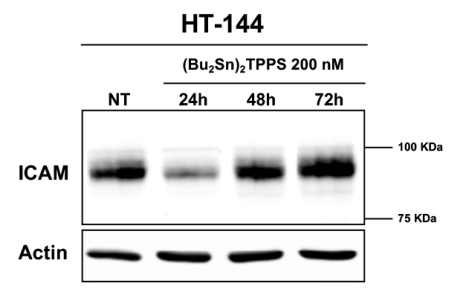

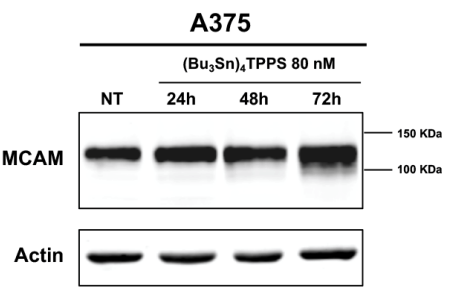
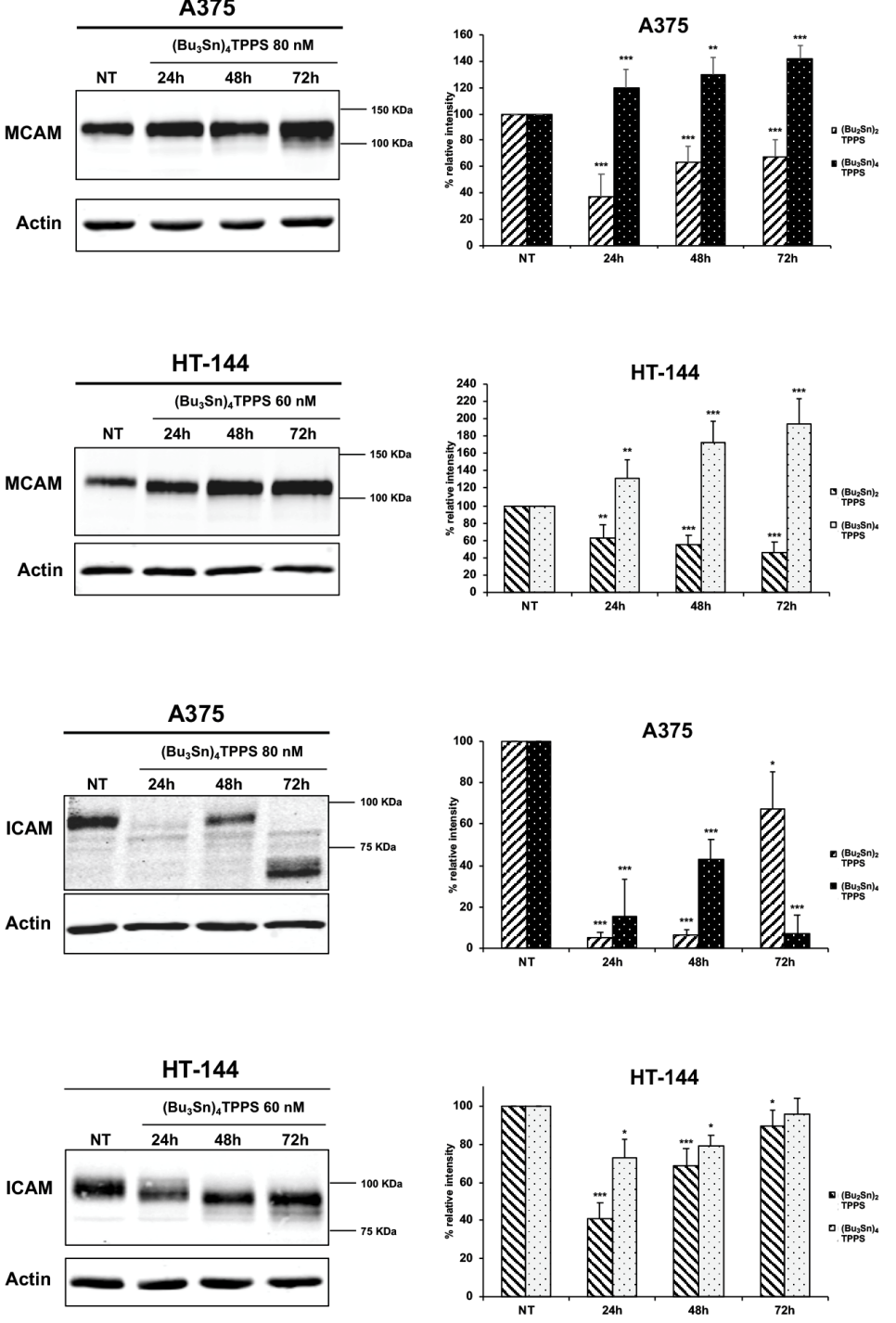

Figure 10. Kinetics of the CAMs expression in A375 and HT-144 cells treated with $\left(\mathrm{Bu}_{2} \mathrm{Sn}\right)_{2} \mathrm{TPPS}$ and $\left(\mathrm{Bu}_{3} \mathrm{Sn}\right)_{4}$ TPPS. The kinetics of MCAM $(\mathbf{A}, \mathbf{B})$ and $\operatorname{ICAM}(\mathbf{C}, \mathbf{D})$ expression was analysed in $(\mathbf{A}, \mathbf{C})$ A375 and in (B,D) HT-144 cell lines in response to the treatment with $250 \mathrm{nM}$ and $200 \mathrm{nM}$ of $\left(\mathrm{Bu}_{2} \mathrm{Sn}\right)_{2}$ TPPS (left and right panels) and with $80 \mathrm{nM}$ and $60 \mathrm{nM}$ of $\left(\mathrm{Bu}_{3} \mathrm{Sn}\right)_{4}$ TPPS (middle and right panels) respectively, for $24 \mathrm{~h}, 48 \mathrm{~h}$ and $72 \mathrm{~h}$, through western blot experiments. The analysis of the $\beta$-actin expression (A, B, C and D, lower panels) was used to confirm the equal protein loading. The error bars indicate the standard deviation. The Student's t-test was used to the analysis of statistical significance: ${ }^{*} p<0.05$ was considered significant; ${ }^{* *} p<0.01$ highly significant; ${ }^{* * *} p<0.001$ very highly significant $(\mathbf{A}, \mathbf{B}, \mathbf{C}$ and $\mathbf{D}$, right panels).

\subsection{Analysis of Melanoma Cell Migration}

Indeed, a complex network of adhesion receptors and signalling molecules are involved in the multistep process required to manage the cell migration, that play a key role on the aggressive metastatic trend of melanoma [43]. Therefore, in A375 and HT-144 cell lines treated for $72 \mathrm{~h}$ with $250 \mathrm{nM}$ and $200 \mathrm{nM}$ of $\left(\mathrm{Bu}_{2} \mathrm{Sn}\right)_{2} \mathrm{TPPS}$, respectively, and with $80 \mathrm{nM}$ and $60 \mathrm{nM}$ of $\left(\mathrm{Bu}_{3} \mathrm{Sn}\right)_{4} \mathrm{TPPS}$, respectively, we analysed the cellular migration ability (Figure 11). In particular, through the migration assay, we showed that the treatment for $72 \mathrm{~h}$ with $\left(\mathrm{Bu}_{2} \mathrm{Sn}\right)_{2}$ TPPS and with $\left(\mathrm{Bu}_{3} \mathrm{Sn}\right)_{4} \mathrm{TPPS}$ decreases the migration ability of A375 cells (by $50.27 \%$ and $57.27 \%$, respectively) (Figure 11A,B) and of HT-144 cells (by $32.8 \%$ and $38.2 \%$, respectively) (Figure $11 \mathrm{C}, \mathrm{D}$ ), compared to untreated cells (NT). In conclusion, our 
results show that $\left(\mathrm{Bu}_{2} \mathrm{Sn}\right)_{2}$ TPPS and $\left(\mathrm{Bu}_{3} \mathrm{Sn}\right)_{4}$ TPPS treatment inhibit the migration and the spreading of melanoma cells, thus suggesting that could play a main role on the treatment of metastatic melanoma.

A

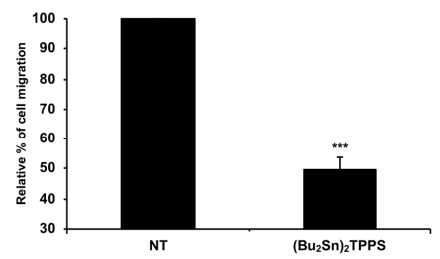

B

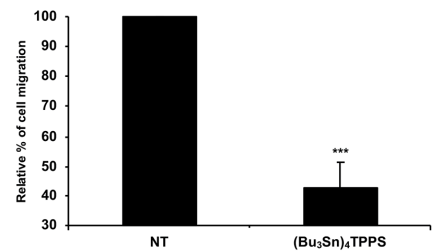

C
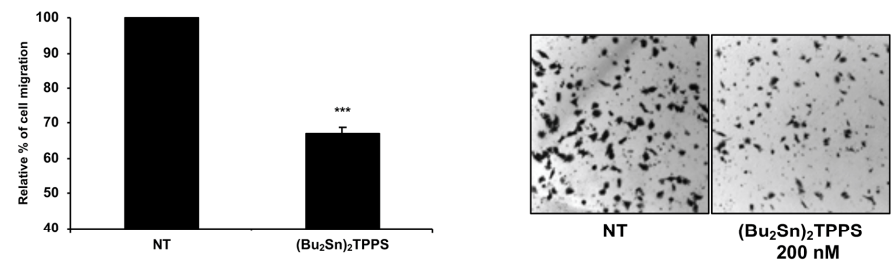

D $\mathrm{HT}-144\left(\mathrm{Bu}_{3} \mathrm{Sn}\right)_{4}$ TPPS
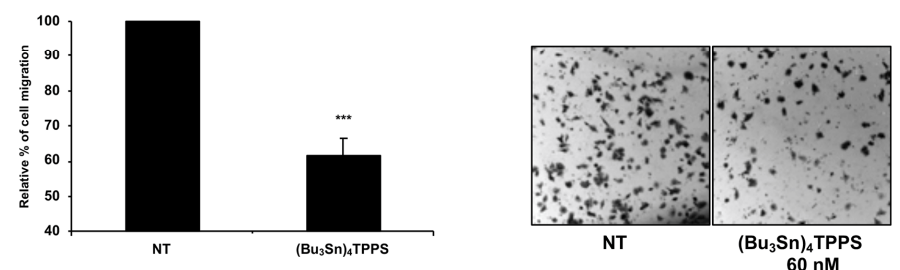

Figure 11. The treatment with nanomolar concentrations of $\left(\mathrm{Bu}_{2} \mathrm{Sn}\right)_{2} \mathrm{TPPS}$ and $\left(\mathrm{Bu}_{3} \mathrm{Sn}\right)_{4} \mathrm{TPPS}$ inhibit the migration of A375 and HT-144 melanoma cells. The (A,B) A375 and (C,D) HT-144 melanoma cells untreated (NT) or treated for $72 \mathrm{~h}$ with (A) $250 \mathrm{nM},\left(\text { C) } 200 \mathrm{nM} \text { of (Bu } \mathrm{Bu}_{2} \mathrm{Sn}\right)_{2} \mathrm{TPPS}$ and with (B) $80 \mathrm{nM}$, (D) $60 \mathrm{nM}$ of $\left(\mathrm{Bu}_{3} \mathrm{Sn}\right)_{4} \mathrm{TPPS}$ respectively, were plated in the inner chamber of a 24-well culture plate with PET membrane $\left(8 \mu \mathrm{m}\right.$ pore size) and incubated at $37^{\circ} \mathrm{C}$ for $16 \mathrm{~h}$. The migrated cells fixed and stained, were counted under phase contrast microscope (Leica). The number of treated migrating cells, are expressed as a per cent of the untreated migrating cells and reported in the histograms (A-D, left panels) as the mean values of almost three different experiments performed in triplicate. The error bars indicate the standard deviation and statistical significance was analysed by the Student's $t$-test: ${ }^{*} p<$ 0.05 was considered significant; ${ }^{* *} p<0.01$ highly significant; ${ }^{* * *} p<0.001$ very highly significant. 


\subsection{Expression of STAT3 Signalling Protein}

The STAT3 protein is often constitutively activated in melanoma cells and its inhibition in melanoma induces cell death, tumour regression and the inhibition of metastatic dissemination [45,46]. Therefore, in A375 (Figure 12A) and in HT-144 (Figure 12B) cell lines treated for $24 \mathrm{~h}, 48 \mathrm{~h}$ and $72 \mathrm{~h}$ with $\left(\mathrm{Bu}_{2} \mathrm{Sn}\right)_{2} \mathrm{TPPS}\left(250 \mathrm{nM}\right.$ and $200 \mathrm{nM}$, respectively) and with $\left(\mathrm{Bu}_{3} \mathrm{Sn}\right)_{4} \mathrm{TPPS}(80 \mathrm{nM}$ and $60 \mathrm{nM}$, respectively), we analysed through western blot the expression of STAT3 signalling protein (Figure 12). In particular, we showed in both cell lines treated with $\left(\mathrm{Bu}_{2} \mathrm{Sn}\right)_{2} \mathrm{TPPS}$ (Figure 12A,B, upper and lower panels) and with $\left(\mathrm{Bu}_{3} \mathrm{Sn}\right)_{4}$ TPPS (Figure 12A,B, middle and lower panels), the decreased expression of STAT3 compared to untreated cells (NT). In conclusion, these results indicate that in melanoma cells, the STAT3 signalling protein is a target of the $\left(\mathrm{Bu}_{2} \mathrm{Sn}\right)_{2}$ TPPS and $\left(\mathrm{Bu}_{3} \mathrm{Sn}\right)_{4}$ TPPS that could mediate the inhibition of melanoma proliferation and metastatic dissemination weakened by these complexes.

A

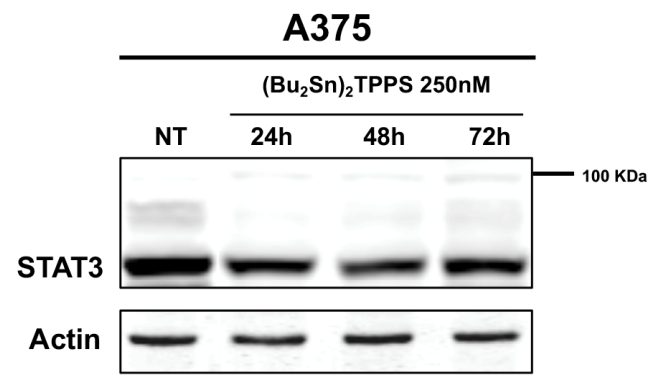

A375

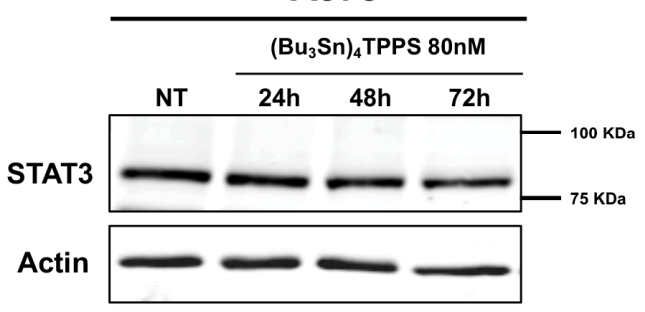

B

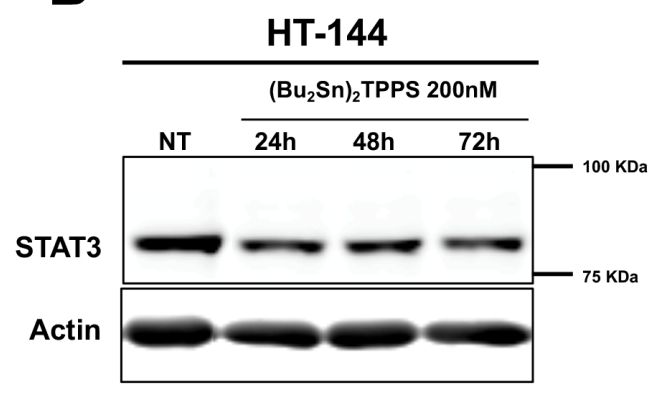

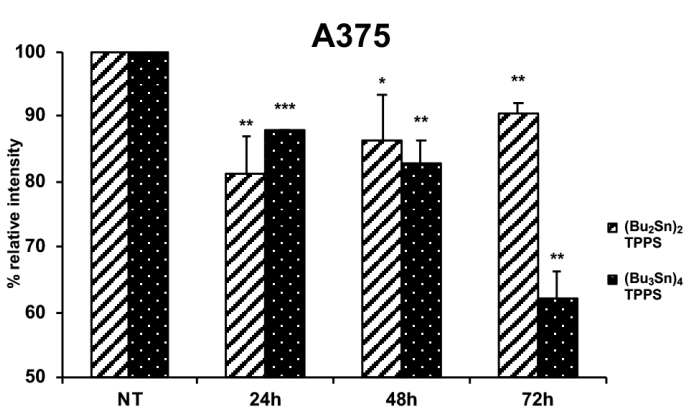

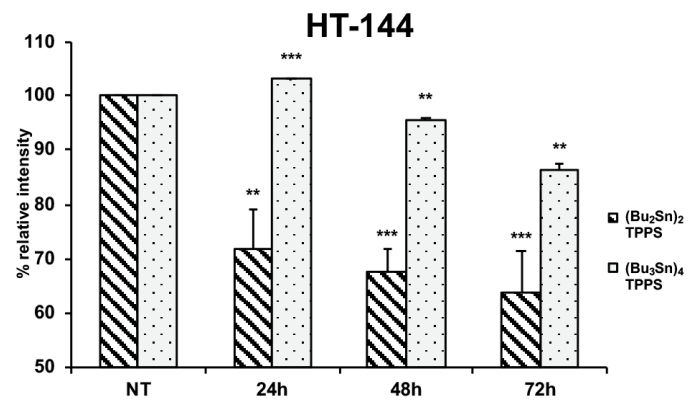

Figure 12. Kinetics of STAT3 expression in A375 and HT-144 melanoma cells treated with $\left(\mathrm{Bu}_{2} \mathrm{Sn}\right)_{2} \mathrm{TPPS}$ and $\left(\mathrm{Bu}_{3} \mathrm{Sn}\right)_{4}$ TPPS. The kinetics of STAT3 expression was analysed in (A) A375 and (B) HT-144 cell lines in response to the treatment with $250 \mathrm{nM}$ and $200 \mathrm{nM}$ of $\left(\mathrm{Bu}_{2} \mathrm{Sn}\right)_{2}$ TPPS (A and $\mathbf{B}$, higher and lower panels) and with $80 \mathrm{nM}$ and $60 \mathrm{nM}$ of $\left(\mathrm{Bu}_{3} \mathrm{Sn}\right)_{4} \mathrm{TPPS}$ (A and $\mathbf{B}$, middle and lower panels) respectively, for $24 \mathrm{~h}, 48 \mathrm{~h}$ and $72 \mathrm{~h}$, through western blot experiments. The analysis of the $\beta$-actin expression $(\mathbf{A}, \mathbf{B})$ was used to confirm the equal protein loading. The error bars indicate the standard deviation. The Student's $t$-test was used to the analysis of statistical significance: ${ }^{*} p<0.05$ was considered significant; ${ }^{* *} p<0.01$ highly significant; ${ }^{* * *} p<0.001$ very highly significant (A and $\mathbf{B}$, lower panels). 


\section{Discussion}

Melanoma is one of the most treatment-refractory malignancies, notorious for its propensity to metastasize. Indeed, notwithstanding the effectiveness of new therapeutic approaches such as immunotherapies and targeted therapies [4], the melanoma field is in great need to identify new therapeutic approaches. Therefore, to improve the research of potential anticancer drugs, we studied the effects of the treatment with nanomolar concentrations of two organotin(IV) complexes of meso-tetra(4-sulfonatophenyl)porphine, $\left(\mathrm{Bu}_{2} \mathrm{Sn}\right)_{2} \mathrm{TPPS}$ and $\left(\mathrm{Bu}_{3} \mathrm{Sn}\right)_{4} \mathrm{TPPS}$, on the growth and on the metastatic dissemination of some human melanoma cell lines. In particular, we showed the induction of a dose-dependent inhibition of cellular growth and respectively the G2/M and the G0/G1 cell cycle arrest, the increased expression of the full-length PARP-1 as well as the inhibition of the cell colony formation and cell migration. PARP-1(ADP-ribosyltransferase-1), a member of the poly-ADP-ribose polymerase family, is involved in many different processes such as DNA single and double strand break repair [47], chromatin modification, transcriptional regulation and cell death [36]. The activation of PARP- 1 follows his binding to the DNA strand breaks and enables PARP-1 to synthetize poly(ADP-ribose) (PAR) and also to increase its own expression [47]. Therefore, the hypothesis that the melanoma cells treatment with nanomolar concentrations of $\left(\mathrm{Bu}_{2} \mathrm{Sn}\right)_{2}$ TPPS and $\left(\mathrm{Bu}_{3} \mathrm{Sn}\right)_{4}$ TPPS induces DNA damage, elicits the increased expression of PARP-1 that, however, is not sufficient to repair an overwhelming amount of DNA damage and to avoid the consequent block of cell cycle. However, in treated M74 cells we reported a lower increase of PARP-1 expression compared to the expression level of PARP-1 in A375 and HT-144 treated cells, probably due to the low expression in M74 cells, of a PARP-1-activating protein such as the p53 protein [34,48]. Furthermore, the A375, HT-144 and M74 human melanoma cell lines harbouring the mutation V600E of BRAF, also express the mutated form of several common and different proteins such as ATM in HT-144 cells, instead, in A375 and M74 cells the promoter of TERT is mutated [32-34], thus eliciting the reported different sensitivity to the treatment with $\left(\mathrm{Bu}_{2} \mathrm{Sn}\right)_{2} \mathrm{TPPS}$ and $\left(\mathrm{Bu}_{3} \mathrm{Sn}\right)_{4}$ TPPS. Indeed, the hydrophobic butyl components of the $\left(\mathrm{Bu}_{2} \mathrm{Sn}\right)_{2} \mathrm{TPPS}$ and the $\left(\mathrm{Bu}_{3} \mathrm{Sn}\right)_{4} \mathrm{TPPS}$, can directly interact with DNA and in particular, the tin of the organotin(IV) compounds can bind not only to the DNA bases but also the functional groups of the DNA grooves and the phosphate of the DNA phosphodiester backbones [11-13,15]. Therefore, the high DNA binding affinity of these organotin(IV) compounds and mostly of $\left(\mathrm{Bu}_{3} \mathrm{Sn}\right)_{4} \mathrm{TPPS}$, elicits the alteration of the DNA conformation [15] and the induction of DNA damage suggested by the increased expression of the full-length PARP-1 as well as by the inhibition of the growth and by the blockage of the cell cycle that we showed in treated melanoma cells. In particular, our hypothesis is that $\left(\mathrm{Bu}_{3} \mathrm{Sn}\right)_{4} \mathrm{TPPS}$ has a higher DNA backbone affinity compared to $\left(\mathrm{Bu}_{2} \mathrm{Sn}\right)_{2}$ TPPS and therefore the higher alteration of the DNA conformation could explain the earlier stop of the cell cycle reported in $\left(\mathrm{Bu}_{3} \mathrm{Sn}\right)_{4} \mathrm{TPPS}$ treated cells. Interestingly, we also showed in treated melanoma cells the decreased expression of the protein cyclin D1, a key regulator of the G1/S but also of the G2/M phase transition [42]. Moreover, cyclin D1 can promote cancer formation and cancer survival through the regulation of transcription, DNA damage and repair, the induction of chromosomal instability as well as the enhancement of angiogenesis, cell migration and invasion $[49,50]$. Therefore, in the light of the polyhedral functions of cyclin D1, the inhibition of cancer growth and metastatic diffusion induced by these compounds in melanoma cells, could be also mediated by the inhibition of cyclin D1 expression. Furthermore, the treatment of melanoma cells carrying the BRAF mutation V600E with nanomolar concentrations of $\left(\mathrm{Bu}_{2} \mathrm{Sn}\right)_{2}$ TPPS and $\left(\mathrm{Bu}_{3} \mathrm{Sn}\right)_{4}$ TPPS induces the increased expression of BRAF, notwithstanding the fact these treatments also induce the inhibition of cellular growth, the blockage of the cell cycle, the inhibition of cell colony formation and the inhibition of the expression of a BRAF target such as cyclin D1 [51]. BRAF is a serine-threonine protein kinase mutated in almost the $50 \%-60 \%$ of melanomas [2] mostly harbouring the mutation V600E that increases the protein kinase activity, the consequent activation of the BRAF/MAPK/ERK signalling pathways and therefore the tumour cell growth and proliferation [39]. Therefore, the reported results show that the downstream functions of BRAF, such as melanoma growth, mobility and invasiveness are irreparably compromised, suggest that $\left(\mathrm{Bu}_{2} \mathrm{Sn}\right)_{2} \mathrm{TPPS}$ 
and $\left(\mathrm{Bu}_{3} \mathrm{Sn}\right)_{4}$ TPPS act downstream of BRAF mainly bypassing its functions. Indeed, these results make it appealing to follow up the studies of the signalling pathways inhibited by $\left(\mathrm{Bu}_{2} \mathrm{Sn}\right)_{2} \mathrm{TPPS}$ and $\left(\mathrm{Bu}_{3} \mathrm{Sn}\right)_{4}$ TPPS treatment as very interesting therapeutic strategies. Melanoma can metastasize spreading beyond the primary tumour and this aggressive metastatic trend is mediated by some adhesion receptors that promote the cell migration during each phase of cancer development and progression but also promote the metastatic dissemination of cancer cells [3,43]. In melanoma cells the treatment with nanomolar concentrations of $\left(\mathrm{Bu}_{2} \mathrm{Sn}\right)_{2} \mathrm{TPPS}$ and $\left(\mathrm{Bu}_{3} \mathrm{Sn}\right)_{4} \mathrm{TPPS}$ is mostly associated, although with different outcomes, to a significant decrease of the expression of integrin and CAM adhesion receptors and especially to the consequent inhibition of the cellular motility. The lipophilicity of the butyl moieties [15] enables $\left(\mathrm{Bu}_{2} \mathrm{Sn}\right)_{2} \mathrm{TPPS}$ and $\left(\mathrm{Bu}_{3} \mathrm{Sn}\right)_{4} \mathrm{TPPS}$ to cross and to intercalate the lipid bilayer of the membrane, to bind phospholipids, glycoproteins and receptors, thus modifying the structure and functionality of the membranes [52], could explain the reported results. Therefore, the decreased expression of integrin and CAM adhesion receptors in treated melanoma cells, could inhibit not only the cellular motility, but also the homologous and heterologous interactions between melanoma and endothelial cells thus preventing the cells from assembling in clumps and the melanoma intravasation, extravasation and metastatic spread. Finally, we showed the inhibition of the STAT3 expression, a key protein implicated in the regulation of growth, survival, invasion, migration and metastatic spread of tumour cells [53]. Therefore, our hypothesis is that the STAT3 inhibition could also mediate the inhibition of melanoma proliferation and metastatic dissemination that we showed in treated melanoma cells.

The available chemotherapeutic drugs have a generally low effect on the growth of melanoma cells but the results that we show suggest that nanomolar concentrations of $\left(\mathrm{Bu}_{2} \mathrm{Sn}\right)_{2} \mathrm{TPPS}$ and $\left(\mathrm{Bu}_{3} \mathrm{Sn}\right)_{4} \mathrm{TPPS}$ could target multiple molecular pathways in melanoma cells. Therefore, $\left(\mathrm{Bu}_{2} \mathrm{Sn}\right)_{2} \mathrm{TPPS}$ and $\left(\mathrm{Bu}_{3} \mathrm{Sn}\right)_{4}$ TPPS, for their role in the regression of melanoma motility and metastatic dissemination, could deeply interfere with the melanoma progression as new strategies for an effective treatment of this highly invasive tumour.

Author Contributions: Conceptualization, G.B., F.C., T.F. and C.P.; validation, G.B. and F.C.; investigation, G.B., F.C., F.D.L., C.D.S., T.F. and C.P.; resources, G.B., T.F. and C.P.; writing-original draft preparation, G.B.; writing-review and editing, G.B., T.F. and C.P.; supervision, G.B.; funding acquisition, G.B.

Funding: This work was supported by the "Ministero dell'Istruzione, dell'Università e della Ricerca (MIUR) (MERIT/FIRB Project RBNE08PA9T) and by the Italian Ministry of Economy and Finance (FaReBio di Qualità).

Acknowledgments: We wish to thank C. Alcaide-Loridan (Paris Diderot University, Paris, Institut Jacques Monod) for providing melanoma cell lines, M. Di Carlo (IRIB-CNR) and P. Picone (IRIB-CNR) for IC 50 values calculation.

Conflicts of Interest: The authors declare no conflict of interest. The founders had no role in the design of the study; in the collection, analyses, or interpretation of data; in the writing of the manuscript, or in the decision to publish the results.

\section{References}

1. Siegel, R.L.; Miller, K.D.; Jemal, A. Cancer statistics, 2019. Ca A Cancer J. Clin. 2019, 69, 7-34. [CrossRef] [PubMed]

2. Schadendorf, D.; van Akkooi, A.C.J.; Berking, C.; Griewank, K.G.; Gutzmer, R.; Hauschild, A.; Stang, A.; Roesch, A.; Ugurel, S. Melanoma. Lancet 2018, 392, 971-984. [CrossRef]

3. Shain, A.H.; Bastian, B.C. From melanocytes to melanomas. Nat. Rev. Cancer 2016, 16, 345-358. [CrossRef] [PubMed]

4. Mattia, G.; Puglisi, R.; Ascione, B.; Malorni, W.; Care, A.; Matarrese, P. Cell death-based treatments of melanoma: Conventional treatments and new therapeutic strategies. Cell Death Dis. 2018, 9, 112. [CrossRef]

5. Gershenwald, J.E.; Scolyer, R.A.; Hess, K.R.; Sondak, V.K.; Long, G.V.; Ross, M.I.; Lazar, A.J.; Faries, M.B.; Kirkwood, J.M.; McArthur, G.A.; et al. Melanoma staging: Evidence-based changes in the American Joint Committee on Cancer eighth edition cancer staging manual. Ca A Cancer J. Clin. 2017, 67, 472-492. [CrossRef]

6. Devi, J.; Yadav, J. Recent Advancements in Organotin(IV) Complexes as Potential Anticancer Agents. Anti-Cancer Agents Med. Chem. 2018, 18, 335-353. [CrossRef] 
7. Arjmand, F.P.S.; Tabassum, S.; Pettinari, C. Organo-tin antitumor compounds: Their present status in drug development and future perspectives. Inorg. Chim. Acta 2014, 423, 26-37. [CrossRef]

8. Pellerito, A.; Fiore, T.; Giuliani, A.M.; Maggio, F.; Pellerito, L.; Vitturi, R.; Colomba, M.S.; Barbieri, R. Organometallic complexes with biological molecules. 8. Synthesis, solid state and in vivo investigation of triorganotin(IV) derivatives of L-homocysteic acid. Appl. Organomet. Chem. 1997, 11, 601-616. [CrossRef]

9. Ruisi, G.; Silvestri, A.; Lo Guidice, M.T.; Barbieri, R.; Atassi, G.; Huber, F.; Gratz, K.; Lamartina, L. The antitumor activity of di-n-butyltin(IV) glycylglycinate, and the correlation with the structure of dialkyltin(IV) glycylglycinates in solution studied by conductivity measurements and by infrared, nuclear magnetic resonance, and Mossbauer spectroscopic methods. J. Inorg. Biochem. 1985, 25, 229-245.

10. Huber, F.; Roge, G.; Carl, L.; Atassi, G.; Spreafico, F.; Filippeschi, S.; Barbieri, R.; Silvestri, A.; Rivarola, E.; Ruisi, G.; et al. Studies on the Anti-Tumor Activity of Di-Organotin(Iv) and Tri-Organotin(Iv) Complexes of Amino-Acids and Related-Compounds, of 2-Mercaptoethanesulphonate, and of Purine-6-Thiol. J. Chem. Soc. Dalton 1985. [CrossRef]

11. Casini, A.; Messori, L.; Orioli, P.; Gielen, M.; Kemmer, M.; Willem, R. Interactions of two cytotoxic organotin(IV) compounds with calf thymus DNA. J. Inorg. Biochem. 2001, 85, 297-300. [CrossRef]

12. Devi, J.; Pachwania, S. Recent advancements in DNA interaction studies of organotin (IV) complexes. Inorg. Chem. Commun. 2018, 91, 44-62. [CrossRef]

13. Barbieri, R.; Silvestri, A. The interaction of native DNA with dimethyltin(IV) species. J. Inorg. Biochem. 1991, 41, 31-35. [CrossRef]

14. Costa, M.A.; Pellerito, L.; Izzo, V.; Fiore, T.; Pellerito, C.; Melis, M.; Musmeci, M.T.; Barbieri, G. Diorganotin(IV) and triorganotin(IV) complexes of meso-tetra(4-sulfonatophenyl)porphine induce apoptosis in A375 human melanoma cells. Cancer Lett. 2006, 238, 284-294. [CrossRef] [PubMed]

15. Aydinoglu, S.; Biver, T.; Figuccia, S.; Fiore, T.; Montanaro, S.; Pellerito, C. Studies on DNA interaction of organotin(IV) complexes of meso-tetra(4-sulfonatophenyl)porphine that show cellular activity. J. Inorg. Biochem. 2016, 163, 311-317. [CrossRef] [PubMed]

16. Pellerito, C.; Morana, O.; Ferrante, F.; Calvaruso, G.; Notaro, A.; Sabella, S.; Fiore, T. Synthesis, chemical characterization, computational studies and biological activity of new DNA methyltransferases (DNMTs) specific inhibitor. Epigenetic regulation as a new and potential approach to cancer therapy. J. Inorg. Biochem. 2015, 150, 18-27. [CrossRef] [PubMed]

17. Barbieri, R. QSAR approach to understand the antitumour activity of organotins. Inorg. Chim. Acta 1992, 191, 253-259. [CrossRef]

18. Chwilkowska, A.; Saczko, J.; Modrzycka, T.; Marcinkowska, A.; Malarska, A.; Bielewicz, J.; Patalas, D.; Banas, T. Uptake of photofrin II, a photosensitizer used in photodynamic therapy, by tumour cells in vitro. Acta Biochim. Pol. 2003, 50, 509-513.

19. Dong, X.; Chen, H.; Qin, J.; Wei, C.; Liang, J.; Liu, T.; Kong, D.; Lv, F. Thermosensitive porphyrin-incorporated hydrogel with four-arm PEG-PCL copolymer (II): Doxorubicin loaded hydrogel as a dual fluorescent drug delivery system for simultaneous imaging tracking in vivo. Drug Deliv. 2017, 24, 641-650. [CrossRef]

20. Huang, H.; Song, W.; Rieffel, J.; Lovell, J.F. Emerging applications of porphyrins in photomedicine. Front. Phys. 2015, 3. [CrossRef]

21. Xiao, X.; Liang, J.W.; Xie, J.Y.; Liu, X.; Zhu, D.S.; Dong, Y. Organotin(IV) carboxylates based on 2-(1,3-dioxo-1H-benzo[de] isoquinolin-2(3H)-yl)acetic acid: Syntheses, crystal structures, luminescent properties and antitumor activities. J. Mol. Struct. 2017, 1146, 233-241. [CrossRef]

22. Barbieri, F.; Viale, M.; Sparatore, F.; Favre, A.; Cagnoli, M.; Bruzzo, C.; Novelli, F.; Alama, A. Cytotoxicity in vitro and preliminary antitumor activity in vivo of a novel organotin compound. Anticancer Res. 2000, 20, 977-980. [PubMed]

23. Costa, M.A.; Zito, F.; Emma, M.R.; Pellerito, L.; Fiore, T.; Pellerito, C.; Barbieri, G. Apoptosis and cell growth arrest in A375 human melanoma cells by diorganotin(IV) and triorganotin(IV) complexes of [meso-Tetra(4-sulfonatophenyl)porphine] manganese(III)chloride. Int. J. Oncol. 2011, 38, 693-700. [CrossRef] [PubMed]

24. Mazzaglia, A.; Bondi, M.L.; Scala, A.; Zito, F.; Barbieri, G.; Crea, F.; Vianelli, G.; Mineo, P.; Fiore, T.; Pellerito, C.; et al. Supramolecular assemblies based on complexes of nonionic amphiphilic cyclodextrins and a meso-tetra(4-sulfonatophenyl)porphine tributyltin(IV) derivative: Potential nanotherapeutics against melanoma. Biomacromolecules 2013, 14, 3820-3829. [CrossRef] 
25. Costa, M.A.; Gulino, L.; Pellerito, L.; Fiore, T.; Pellerito, C.; Barbieri, G. Effects of two organotin(IV)(sulfonatophenyl)porphinates on MAPKs and on the growth of A375 human melanoma cells. Oncol. Rep. 2009, 21, 593-599. [CrossRef]

26. Giard, D.J.; Aaronson, S.A.; Todaro, G.J.; Arnstein, P.; Kersey, J.H.; Dosik, H.; Parks, W.P. In vitro cultivation of human tumors: Establishment of cell lines derived from a series of solid tumors. J. Natl. Cancer Inst. 1973, 51, 1417-1423. [CrossRef]

27. Tsuruo, T.; Fidler, I.J. Differences in drug sensitivity among tumor cells from parental tumors, selected variants, and spontaneous metastases. Cancer Res. 1981, 41, 3058-3064.

28. Fogh, J.; Fogh, J.M.; Orfeo, T. One hundred and twenty-seven cultured human tumor cell lines producing tumors in nude mice. J. Natl. Cancer Inst. 1977, 59, 221-226. [CrossRef]

29. Gervois, N.; Heuze, F.; Diez, E.; Jotereau, F. Selective expansion of a specific anti-tumor CD8+ cytotoxic T lymphocyte clone in the bulk culture of tumor-infiltrating lymphocytes from a melanoma patient: Cytotoxic activity and T cell receptor gene rearrangements. Eur. J. Immunol. 1990, 20, 825-831. [CrossRef]

30. Costantini, F.; Barbieri, G. The HLA-DR mediated signalling increases the migration and invasion of melanoma cells, the expression and lipid raft recruitment of adhesion receptors, PD-L1 and signal transduction proteins. Cell Signal 2017, 36, 189-203. [CrossRef]

31. Valster, A.; Tran, N.L.; Nakada, M.; Berens, M.E.; Chan, A.Y.; Symons, M. Cell migration and invasion assays. Methods 2005, 37, 208-215. [CrossRef] [PubMed]

32. Vallarelli, A.F.; Rachakonda, P.S.; Andre, J.; Heidenreich, B.; Riffaud, L.; Bensussan, A.; Kumar, R.; Dumaz, N. TERT promoter mutations in melanoma render TERT expression dependent on MAPK pathway activation. Oncotarget 2016, 7, 53127-53136. [CrossRef] [PubMed]

33. Ramsay, J.; Birrell, G.; Baumann, K.; Bodero, A.; Parsons, P.; Lavin, M. Radiosensitive melanoma cell line with mutation of the gene for ataxia telangiectasia. Br. J. Cancer 1998, 77, 11-14. [CrossRef] [PubMed]

34. Gnjatic, S.; Cai, Z.; Viguier, M.; Chouaib, S.; Guillet, J.G.; Choppin, J. Accumulation of the p53 protein allows recognition by human CTL of a wild-type p53 epitope presented by breast carcinomas and melanomas. J. Immunol. 1998, 160, 328-333. [PubMed]

35. Shiloh, Y.; Ziv, Y. The ATM protein kinase: Regulating the cellular response to genotoxic stress, and more. Nat. Rev. Mol. Cell Biol. 2013, 14, 197-210. [CrossRef]

36. Jackson, S.P.; Bartek, J. The DNA-damage response in human biology and disease. Nature 2009, 461, 1071-1078. [CrossRef]

37. Khanna, K.K.; Jackson, S.P. DNA double-strand breaks: Signaling, repair and the cancer connection. Nat. Genet. 2001, 27, 247-254. [CrossRef]

38. Lazebnik, Y.A.; Kaufmann, S.H.; Desnoyers, S.; Poirier, G.G.; Earnshaw, W.C. Cleavage of poly(ADP-ribose) polymerase by a proteinase with properties like ICE. Nature 1994, 371, 346-347. [CrossRef]

39. Satyamoorthy, K.; Li, G.; Gerrero, M.R.; Brose, M.S.; Volpe, P.; Weber, B.L.; Van Belle, P.; Elder, D.E.; Herlyn, M. Constitutive mitogen-activated protein kinase activation in melanoma is mediated by both BRAF mutations and autocrine growth factor stimulation. Cancer Res. 2003, 63, 756-759.

40. Hustedt, N.; Durocher, D. The control of DNA repair by the cell cycle. Nat. Cell Biol. 2016, 19, 1-9. [CrossRef]

41. Bai, J.; Li, Y.; Zhang, G. Cell cycle regulation and anticancer drug discovery. Cancer Biol. Med. 2017, 14, 348-362. [CrossRef] [PubMed]

42. Li, Y.; Qin, Y.; Yang, C.; Zhang, H.; Li, Y.; Wu, B.; Huang, J.; Zhou, X.; Huang, B.; Yang, K.; et al. Cardamonin induces ROS-mediated G2/M phase arrest and apoptosis through inhibition of NF-kappaB pathway in nasopharyngeal carcinoma. Cell Death Dis. 2017, 8, e3024. [CrossRef] [PubMed]

43. Alizadeh, A.M.; Shiri, S.; Farsinejad, S. Metastasis review: From bench to bedside. Tumour Biol. J. Int. Soc. Oncodev. Biol. Med. 2014, 35, 8483-8523. [CrossRef] [PubMed]

44. Bellis, S.L.; Miller, J.T.; Turner, C.E. Characterization of tyrosine phosphorylation of paxillin in vitro by focal adhesion kinase. J. Biol. Chem. 1995, 270, 17437-17441. [CrossRef]

45. Xie, T.X.; Wei, D.; Liu, M.; Gao, A.C.; Ali-Osman, F.; Sawaya, R.; Huang, S. Stat3 activation regulates the expression of matrix metalloproteinase-2 and tumor invasion and metastasis. Oncogene 2004, 23, 3550-3560. [CrossRef]

46. Niu, G.; Heller, R.; Catlett-Falcone, R.; Coppola, D.; Jaroszeski, M.; Dalton, W.; Jove, R.; Yu, H. Gene therapy with dominant-negative Stat 3 suppresses growth of the murine melanoma B16 tumor in vivo. Cancer Res. 1999, 59, 5059-5063. 
47. De Vos, M.; Schreiber, V.; Dantzer, F. The diverse roles and clinical relevance of PARPs in DNA damage repair: Current state of the art. Biochem. Pharmacol. 2012, 84, 137-146. [CrossRef]

48. Montero, J.; Dutta, C.; van Bodegom, D.; Weinstock, D.; Letai, A. p53 regulates a non-apoptotic death induced by ROS. Cell Death Differ. 2013, 20, 1465-1474. [CrossRef]

49. Hydbring, P.; Malumbres, M.; Sicinski, P. Non-canonical functions of cell cycle cyclins and cyclin-dependent kinases. Nat. Rev. Mol. Cell Biol. 2016, 17, 280-292. [CrossRef]

50. Jirawatnotai, S.; Sittithumcharee, G. Paradoxical roles of cyclin D1 in DNA stability. Dna Repair 2016, 42, 56-62. [CrossRef]

51. Pathria, G.; Garg, B.; Garg, K.; Wagner, C.; Wagner, S.N. Dual c-Jun N-terminal kinase-cyclin D1 and extracellular signal-related kinase-c-Jun disjunction in human melanoma. Br. J. Dermatol. 2016, 175, 1221-1231. [CrossRef] [PubMed]

52. Gennari, A.; Viviani, B.; Galli, C.L.; Marinovich, M.; Pieters, R.; Corsini, E. Organotins induce apoptosis by disturbance of $[\mathrm{Ca}(2+)](\mathrm{i})$ and mitochondrial activity, causing oxidative stress and activation of caspases in rat thymocytes. Toxicol. Appl. Pharmacol. 2000, 169, 185-190. [CrossRef] [PubMed]

53. Lutticken, C.; Wegenka, U.M.; Yuan, J.P.; Buschmann, J.; Schindler, C.; Ziemiecki, A.; Harpur, A.G.; Wilks, A.F.; Yasukawa, K.; Taga, T.; et al. Association of Transcription Factor Aprf and Protein-Kinase Jak1 with the Interleukin-6 Signal Transducer Gp130. Science 1994, 263, 89-92. [CrossRef] [PubMed]

(C) 2019 by the authors. Licensee MDPI, Basel, Switzerland. This article is an open access article distributed under the terms and conditions of the Creative Commons Attribution (CC BY) license (http://creativecommons.org/licenses/by/4.0/). 